\title{
An overview of social responsibility dimensions in international business
}

DOI:

10.4337/9781788114127.00009

\section{Document Version}

Accepted author manuscript

Link to publication record in Manchester Research Explorer

\section{Citation for published version (APA):}

Sinkovics, N., Sinkovics, R. R., \& Archie-Acheampong, J. (2019). An overview of social responsibility dimensions in international business. In L. C. Leonidou, C. S. Katsikeas, S. Samiee, \& C. N. Leonidou (Eds.), Socially responsible international business: Critical issues and the way forward (pp. 29-71). Edward Elgar Publishing Ltd. https://doi.org/10.4337/9781788114127.00009

Published in:

Socially responsible international business

\section{Citing this paper}

Please note that where the full-text provided on Manchester Research Explorer is the Author Accepted Manuscript or Proof version this may differ from the final Published version. If citing, it is advised that you check and use the publisher's definitive version.

\section{General rights}

Copyright and moral rights for the publications made accessible in the Research Explorer are retained by the authors and/or other copyright owners and it is a condition of accessing publications that users recognise and abide by the legal requirements associated with these rights.

\section{Takedown policy}

If you believe that this document breaches copyright please refer to the University of Manchester's Takedown Procedures [http://man.ac.uk/04Y6Bo] or contact uml.scholarlycommunications@manchester.ac.uk providing relevant details, so we can investigate your claim.

\section{OPEN ACCESS}


This is a pre-print / an Author's Accepted Manuscript (AAM) of an article, to be published by Edward Elgar. Please cite the published article:

Sinkovics, Noemi, Rudolf R. Sinkovics, and Jason Archie-Acheampong (2019), "An overview of social responsibility dimensions in international business," in Socially responsible international business: Critical issues and the way forward, Leonidas $\mathrm{C}$. Leonidou, Costas S. Katsikeas, Saeed Samiee, and Costas N. Leonidou (Eds.). Cheltenham, U.K.: Edward Elgar Publishing, forthcoming. https://www.e-elgar.com/shop/socially-responsible-international-business 


\title{
Chapter 2 - An overview of social responsibility dimensions in international business
}

\author{
Noemi Sinkovics \\ Lecturer in International Business and Management \\ The University of Manchester, Alliance Manchester Business School \\ Booth Street West, Manchester M15 6PB, UK. \\ Noemi.Sinkovics@manchester.ac.uk \\ http://www.research.manchester.ac.uk/portal/Noemi.Sinkovics.html \\ http://orcid.org/0000-0002-5143-6870 \\ and
}

Temple University, Fox School of Business, Department of Strategic Management

Alter Hall, 1801 Liacouras Walk, Philadelphia, PA 19122, USA

Rudolf R. Sinkovics

Professor of International Business

The University of Manchester, Alliance Manchester Business School

Booth Street West, Manchester M15 6PB, UK.

Rudolf.Sinkovics@manchester.ac.uk

http:/www.manchester.ac.uk/research/rudolf.sinkovics

http://orcid.org/0000-0002-4471-5054

and

Lappeenranta University of Technology

Skinnarilankatu 34, PL 20, 53851 Lappeenranta, Finland

and

Temple University, Fox School of Business, Department of Strategic Management

Alter Hall, 1801 Liacouras Walk, Philadelphia, PA 19122, USA

Jason Archie-Acheampong

Postgraduate Research Student

The University of Manchester, Alliance Manchester Business School

Booth Street West, Manchester M15 6PB, UK.

jason.archie-acheampong@manchester.ac.uk

http://orcid.org/0000-0002-6822-0179 


\begin{abstract}
This chapter aims at taking stock of business-responsibility-related studies in international business (IB) research. Key features of this literature review include (1) a broad search strategy capturing both positive and negative aspects of responsibility, (2) not imposing any constraints on the time period, and (3) extending the search to all IB journals included in the Web of Science database. By incorporating both responsible and irresponsible behavior in the search strategy, we are able to provide a holistic map of responsibility-related research in IB.
\end{abstract}

Keywords: corporate social responsibility, corporate social irresponsibility, responsible business 


\section{Introduction}

Peter Buckley’s (2002) seminal paper examining the relevance of international business (IB) research marks the start of an opening towards more critical topics inherent to the nature of IB, such as labor issues in foreign locations, managerial ethics, and corporate social responsibility (CSR). One and a half decades later, Buckley, Doh, and Benischke (2017) suggest that the discipline is in a unique position to focus on the grand challenges of our time and contend that IB scholars can contribute by investigating how multinational enterprises (MNEs) are responding to pressures created by these grand challenges. However, MNEs are often seen as part of the problem rather than the solution (cf. Sinkovics, Hoque, \& Sinkovics, 2016; Wettstein, 2012). As a consequence, the concept of social responsibility may be better conceived of as a continuum, or as degrees, rather than a discrete concept. This is in line with Sinkovics et al.'s (2015) proposition that, when it comes to social constraints, MNEs have three main strategies for responding. They can either attempt to benefit from the existence of these constraints, try to bypass them, or leverage their resources and/or business models to eradicate/reduce them (Sinkovics et al., 2015; Sinkovics, Sinkovics, \& Mo, 2014). Therefore, the continuum of socially responsible behavior stretches from irresponsible and at times malevolent conduct to meaningful action geared towards tackling the symptoms and/or the root causes of grand challenges. Against this background, the objective of this chapter is to take stock of how the IB literature has engaged with the degrees of responsible behavior that make up the continuum of social responsibility. This stock-taking exercise is important for a number of reasons. First and foremost, there are more and more scholars wishing to incorporate responsibility-related aspects into their research endeavors. Yet, this area is relatively new for many IB scholars. It is thus important to know which topics have been covered within the field and to what extent. Furthermore, uncovering areas that are underresearched provides suggestions for future research. Hence, this chapter seeks to provide 
researchers who are new to this topic with a starting point, and others with inspiration for future research.

The extant literature is not short of reviews on the role of businesses in addressing social and environmental problems (e.g.Doh \& Lucea, 2013; Egri \& Ralston, 2008; Holtbrügge \& Dögl, 2012; Kolk, 2016; Kolk \& van Tulder, 2010). While these studies make valuable contributions, they are not without limitations, which arise from (1) the narrowness of the search strategy (e.g. Holtbrügge \& Dögl, 2012), (2) constraints imposed on the time period (e.g. Doh \& Lucea, 2013), and (3) limiting the number of journals investigated (e.g. Kolk, 2016). To this end, the present review attempts to address all three of these limitations and offer a comprehensive literature review. Our search strategy covers a wide range of search terms, aiming at capturing the different degrees of responsibility. We also extend the search to 14 IB journals that are listed in the Web of Science database, arguably making up the universe of IB journals (cf. Tüselmann, Sinkovics, \& Pishchulov, 2016). Lastly, we do not impose any limits on the time period covered.

The structure of this chapter is as follows. The next section introduces the reader to the methodology we adopted. This is followed by a discussion of the findings, organized into eight sub-sections according to the overall themes that emerged from our analysis. The concluding remarks summarize the main observations and the limitations of this study.

\section{Methodology}

We used the Web of Science database to perform our search. We downloaded the abstracts and the associated bibliographic information including the list of all cited references. Tüselmann et al. (2016) categorize 16 journals as IB journals. However, only 14 are included in the Web of Science: Journal of World Business (JWB), Journal of International Business Studies (JIBS), International Business Review (IBR), European Journal of International 
Management (EJIM), Asia Pacific Journal of Management (APJM), Asia Pacific Business Review (APBR), Journal of International Management (JIM), Management Organization Review (MOR), Management International Review (MIR), Critical Perspectives of International Business (CPOIB), Thunderbird International Review (TIR), Global Strategy Journal (GSJ), Multinational Business Review (MBR), and Journal of East West Business (JEWB). Neither Transnational Corporations nor the Journal of Asia Pacific Business is currently available in Web of Science. As we needed the bibliometric information to be in the same file format for the bibliographic coupling analysis, we concentrated our search on the former 14 journals excluded the latter two from the analysis. The search string included a wide range of key words (see Appendix 1) ranging from corporate social responsibility to humiliation and crime. We cast the net as wide as possible in order to identify studies spanning the different degrees of responsibility. Search terms related to corporate irresponsibility were inspired by Tillman et al.’s (2008) operationalization. The remaining search terms were the outcome of an iterative brain-storming process including the consulting of previous review papers and the skimming of preliminary search results. The final search yielded 689 articles. Subsequently, the authors judged the relevance of each article. This process left $484^{1}$ in the sample. The main selection criterion was whether or not the article was of relevance to business responsibility. This relevance could be broad or narrow.

The analysis process followed two steps. First, the freely available VOSviewer software (www.vosviewer.com) was used to perform a bibliographic coupling analysis. In such analysis, the relatedness of items (academic publications) is determined based on the number of references they share (Van Eck \& Waltman, 2014). The underlying assumption is that articles on a certain topic will build on prior research related to the topic of the manuscript. As a consequence, the more references two publications share, the stronger is the

\footnotetext{
${ }^{1}$ The list of references can be obtained from the authors.
} 
expectation that certain commonalities will exist between them. We intentionally set the threshold for the number of shared references at 0 in order to obtain broad themes and assign each publication to a cluster. As the next step involved a textual analysis in NVivo, this very broad clustering was deemed appropriate for our purposes. The analysis yielded 20 clusters in total, of which 12 contained only one publication. In other words, 12 publications did not have any references in common with any other publication in the sample.

After we had determined which article in our sample belonged to which cluster, we imported the abstracts and the bibliographic data into NVivo. The bibliographic information was assigned to each article through the source classification sheet. We supplemented this data with the cluster information obtained from VOSviewer. This allowed us to conduct cross-cluster comparisons. We then performed a more fine-grained thematic analysis in NVivo. While the overall clusters provided an overview of eight general themes in the sample, the NVivo analysis allowed us to drill down and identify sub-themes. By utilizing the source classification sheet, we were also able to draw direct comparisons between journals and examine the development of certain themes over time. The remainder of this chapter will discuss our findings.

\section{Findings}

Table 3.1 provides an overview of the distribution of relevant publications across journals and clusters. The last row shows the total number of relevant papers in each cluster. The last column indicates the total number of relevant papers in each journal. The largest cluster includes 105 studies related to ethics, management, and contextual factors, followed by the cluster containing 87 papers concerned with the antecedents and/or outcomes of CSR. The next three clusters encompass papers on foreign direct investment (FDI) and economic development, institutional dynamics and non-market strategies, and business models and 
entrepreneurship in developing countries, with 65, 61, and 59 papers respectively. Studies linked to corruption-related issues (38 papers), the drivers, implementation, and outcomes of non-market strategies in host countries (37 papers), and articles displaying a critical and/or novel angle (20 papers) represent smaller clusters. The remaining 12 papers do not share any references with other papers. We subsumed them under the category "other". Table 3.2 offers an overview of the clusters and the main themes and sub-themes that emerged from the NVivo analysis.

Our temporal analysis furthermore revealed that 2006 marked the beginning of a new trend that saw a significant rise in responsibility-related publications. Before 2006, the number of papers across all clusters ranged from one to three, with the exception of 1999 , 2004, and 2005 with five, six, and four publications respectively. In 2006 there were 19 publications across the clusters. The annual number of studies published peaked in 2015 at 79 . The rest of this section will discuss each cluster in more depth.

$<$ INSERT Table 3.1 and 3.2 ABOUT HERE $>$

\subsection{Ethics, management and contextual factors}

This cluster can be subdivided into six distinctive themes: (a) leadership, (b) human resource management (HRM), (c) the impact of context and culture on responsible business, (d) marketing ethics, (e) entrepreneurial morality, and (f) theoretical integration efforts.

Studies examining leadership address the contextual antecedents shaping leadership. They furthermore look at the relationship between leadership behavior and business ethics. Results indicate country and industry effects on the nature of business ethics (Schlegelmilch \& Robertson, 1995), implying that managers in more modernized contexts are more inclined to recognize ethical and unethical behavior (Redfern \& Crawford, 2010). The literature depicts different types of leadership, including transformational, ethical, and paternal 
leadership, as well as subordinate influence ethics. In doing so, studies examine the antecedents of leadership behavior and its impact on business ethics.

Transformational leadership is expected to encourage pro-social values among employees, as seen in behavior such as cooperation and volunteering (Muethel, Hoegl, \& Parboteeah, 2011), improve firm performance (Muethel et al., 2011), facilitate authentic relationships between employees and their leaders (Bramming \& Johnsen, 2011), and encourage employee voice (Wang, Hsieh, Tsai, \& Cheng, 2012; Yang \& Liu, 2014). Paternalistic leadership is shown to be characterized by the compassion of leaders (Wei, Zhu, \& Li, 2016). However, further studies have highlighted the ambiguity of paternalistic leadership, as it can take the form of either benevolence or exploitative behavior across different cultural contexts (Mansur, Sobral, \& Goldszmidt, 2017). Subordinate influence ethics examines how the ethics of subordinates influences the behavior of superiors within organizations. Studies uncover a range of relevant macro- and micro-level factors (Karam et al., 2013; Ralston et al., 2009a; Ralston, Egri, Casado, Fu, \& Wangenheim, 2009b).

Ethical leadership within an organization can be derived from a firm's cultural settings (Wang, Chiang, Chou, \& Cheng, 2017). Other studies on the topic emphasize group harmony as an aspect of ethical leadership (Chen, Unal, Leung, \& Xin, 2016). Further evidence suggests that ethical leadership positively influences employee voice behavior, with organizational identification and organizational trust respectively mediating and moderating this relationship (Yang \& Liu, 2014). Lastly, in other studies, intercultural competencies such as self-management, perception management, and relationship management are found to be important factors in effective global responsible management (Miska, Stahl, \& Mendenhall, 2013).

Studies subsumed under HRM can be broadly categorized into (i) equality, diversity, and fairness, (ii) working conditions, (iii) representation, and (iv) employee retention. 
In the area of employee retention, intrinsic rewards lead to an increase in the latter (Tymon, Stumpf, \& Doh, 2010). Furthermore, psychological ownership - which refers to the level of connectedness and commitment an individual demonstrates - is used as a tool for talent management in terms of retaining highly skilled employees (Olckers \& Du Plessis, 2015). In other studies, psychological ownership explains why shareholders remain aligned and participate in their family businesses (Lepez-Vergara \& Botero, 2015). Finally, in the area of employee attractiveness, Newburry, Gardberg, and Sanchez (2014) find that marginalized groups are more attracted to internationally inclined firms that have foreign headquarters.

Within the sub-theme of employee representation, employee voice behavior is depicted as being influenced by organizational socialization (Wu, Tang, Dong, \& Liu, 2015), with associated grievance management systems also influenced by the history and ownership form of the firm, and contributing to productivity and enhanced relationships (Cooke \& Saini, 2015). More nascent theorizing on conflict avoidance demonstrates that employees with high closure needs demonstrate greater tendency towards conflict avoidance (Zhang, Wei, Chao, \& Zheng, 2017). Representational predicaments arise in employees when subordinates experience a lack of employee voice, a lack of vertical feedback channels, and an authoritarian leadership style. Within the area of unionization, early studies detail the role of nationality in the likelihood of unionization but find no relationship effect (Sanyal, 1990). They furthermore address the role of unions in gaining collective bargaining contracts in foreign-owned firms (Sanyal \& Neves, 1992). Research also shows that the cultural orientation of an employee and the organizational culture of the firm impact on employees' attitudes towards union membership (Sarkar, 2009), with trust, cooperation, and honesty depicted as key facets in enabling productive employee-management relationships (Mirowska, 2008). Furthermore, at the firm level, evidence shows that transnational corporations (TNCs) 
strategically enable shifts in organizational and geographical boundaries in order to weaken the bargaining power of unions (Ietto-Gillies, 2017).

The third sub-theme within HRM deals with equality, diversity, and fairness. The role of religion is explored in order to determine its impact on how diversity is managed (Soltani, Syed, Liao, \& Shahi-Sough, 2012) and the workplace affiliation of ethnic minorities (Rao, 2012). Within the theme of gender discrimination, religion is drawn upon to depict how the cultural dynamics of Islamic societies influence gender equality through both informal and formal institutions (Syed, 2008). The formal structures of governmental policies also contribute to the tackling of gender discrimination within the workplace (Patterson \& Walcutt, 2013, 2014). To address gender inequalities, gender quotas are proposed as a means of creating an effective talent management strategy (Tatli, Vassilopoulou, \& Ozbilgin, 2013). Furthermore, on a macro level, utilizing the global social tolerance index, Zanakis, Newburry, and Taras (2016) undertake scale development for the measurement of social tolerance, thus drawing upon gender equality. Innovation and HRM are also examined through the lens of creative capital, as firms manage the diversity of skills and knowledge in order to enhance their overall innovation performance (Veenendaal, van Velzen, \& Looise, 2014). Finally studies find that diversity management has a positive effect on organizational commitment when mediated by employee perceptions of procedural justice (Magoshi \& Chang, 2009).

Within the theme of justice and fairness, distributive justice influences an employee's overall level of organizational commitment and job satisfaction (Leung, Zhu, \& Ge, 2009). From a negative perspective, procedural injustices during promotion processes harm employee commitment and job satisfaction (Wan, Sulaiman, \& Omar, 2012). Furthermore, research has shown how procedural and interactional injustices can exist between hostcountry managers and foreign managers within strategic alliances (Gomes, Cohen, \& Mellahi, 2011). The link between CSR and global talent management is made in order to depict the 
institutional and cultural variances in managerial competency when it comes to addressing CSR issues (Kim \& Scullion, 2011).

Subsumed within the category of HRM, the working conditions of employees are also explored. Evidence shows that work-life balance is influenced by gendered norms, as ideas on flexibility are treated differently across men and women (Gatrell \& Cooper, 2008). Lam, Walter, and Ouyang (2014) address employee well-being by exploring the impact emotional display rules have on job performance, with further studies offering cynicism on the relationship between the happiness of a nation and its overall productivity (Kessler, Taylor, Levine, Wiley, \& Kessler, 2008). Gendered nuances on job satisfaction are evidenced in the overall job satisfaction of female employees and managers, who are more likely to experience conflict as a result of work than family factors (Ren \& Foster, 2011). Collings, Scullion, and Morley (2007) call for the need to design adaptable HRM processes that take into consideration the complexities involved in global staffing. Studies pertaining to employee working conditions address differences in the emotional management of men and women, showing that men tend to demonstrate anger and women sadness in response to hurtful events (Li, Ashkanasy, \& Mehmood, 2017). Studies in this area consider the contextual variances of HRM and have also depicted the experiences of lesbian, gay, bisexual, and transgender (LGBT) expatriates who face personal risks when working in dangerous locations (McPhail \& McNulty, 2015). Relational-based psychological contracts are also used as means by which managers deploy a duty of care towards their subordinates when operating in high-risk environments (Ramirez, Velez-Zapata, \& Madero, 2015). Research has found that, in the case of addressing child labor, MNEs not only follow internationally agreed norms but also deploy HRM practices that are 'multi-domestic'(Kolk \& Van Tulder, 2004). In the area of employee protection, the political orientation of the government and the electoral system have been shown to influence the extent of firm-level redundancies (Goergen, Brewster, \& Wood, 2013). 
The third wider theme is concerned with the role context and culture play in firms' responsible behavior. Studies exploring the interface of religion and business ethics call for a greater level of recognition and understanding of the religious and spiritual context as a predetermining factor in ethical decision making (Ananthram \& Chan, 2016; Liu \& Stening, 2016). Other studies have sought to determine the relationship between the economic context of the firm and work-related values (Froese, 2013), with results showing that economic liberalization has led to higher uncertainty avoidance in firms. Furthermore, using the new institutional economics framework, von Staden (2016) shows that ideology impacts on business ethics, with further research on cultural dimensions finding that societies characterized by conservatism enhance the level of dividend payments in firms (Shao, Kwok, \& Guedhami, 2010). The negative implications of culture are also addressed when examining the impact of close guanxi parties. Although close relationships may foster cooperation between guanxi parties they may also create negative externalities, such as reducing organizational social capital and limiting cooperation between guanxi and non-guanxi parties (Chen, Newburry, \& Park, 2009). In detailing the value systems of entrepreneurs in small and medium-sized enterprises (SMEs), findings demonstrate how entrepreneurial values are derived from embeddedness within the local environment (Del Baldo, 2013).

Although calls have been made to improve research generalizations made on crosscultural measurements (Franke \& Richey, 2010), the sub-theme of cross-cultural variations notably explains how national cultural differences impact on firm behavior. Studies have addressed the impact of culture on unethical negotiation tactics (Al-Khatib, Malshe, \& AbdulKader, 2008) and moral behavior (Husted, Dozier, McMahon, \& Kattan, 1996), and have found that cultural differences and diversity influence the contents of codes of conduct and the moral climate of a firm (Langlois \& Schlegelmilch, 1990; Macklin, Martin, \& Mathison, 2015; Singh, Carasco, Svensson, Wood, \& Callaghan, 2005). In determining the 
evolution of entrepreneurship in ethnic communities, research finds that the contextual entrepreneurial culture influences subsequent entrepreneurial activities (Li, Young, \& Tang, 2012). Amongst these studies, ethical values and beliefs at the firm level are also addressed from a cross-cultural perspective (Lovett, Simmons, \& Kali, 1999; Stajkovic \& Luthans, 1997). In light of differences in the ethical values of different nationalities (Whitman, Townsend, \& Hendrickson, 1999), Forsyth and O'Boyle (2011) demonstrate that the ethical position of a country's inhabitants can impact upon the overall ethical position of a firm (Forsyth \& O'Boyle, 2011). Furthermore, findings on the business goal profiles of managers and professionals show a move beyond goals based solely on growth and wealth, and a greater emphasis towards societal responsibility (Hofstede, 2009).

Findings that emerge from the category of marketing ethics focus on consumer views and attitudes towards online advertising (Wang \& Sun, 2010), cross-national comparisons of sales personnel's ethical and work values (Dubinsky, Jolson, Kotabe, \& Lim, 1991; Whitman et al., 1999), and the incorporation of sustainability practices into firms' overall marketing strategies (Gupta, Czinkota, \& Melewar, 2013). Ethics and trust are found to have an impact on marketing relationships within international marketing channels (Spais \& Kaufmann, 2016). In other studies, the integration of social marketing and social entrepreneurship within educational courses is also examined (Spais \& Beheshti, 2016). In the exploration of unethical marketing behavior by exporting firms, evidence indicates that, when participating firms demonstrate synergy in their values and similarity in ethical codes, the nature of their working relationship is enhanced (Leonidou, Leonidou, Coudounaris, \& Hultman, 2013).

Studies in the category of entrepreneurial morality explore entrepreneurship from an ethical and moral perspective (Petrovskaya, Zaverskiy, \& Kiseleva, 2016), and investigate how entrepreneurial values are derived from a firm's historical, cultural, and social context (Bitros \& Karayiannis, 2010). 
Finally, in the sixth category efforts are made to contextualize business ethics including historical perspectives (Lie, 2016; Rowley \& Oh, 2016a).

\subsection{Corporate social responsibility}

The NVivo analysis yielded eight sub-themes within this cluster: (a) antecedents and consequences of CSR, (b) the role of CSR and stakeholders, (c) corporate political activity, (d) CSR and brand-related issues, (e) environmental responsibility, (f) governance, (g) sustainability, and (h) attitudes towards CSR.

Within the sub-theme of antecedents and consequences of CSR, a number of studies deal with the organizational benefits of CSR (Gupta \& Kumar, 2013; Munoz, de Pablo, \& Pena, 2015). Findings show that CSR contributes to firm performance through its influence on the marketing competence of the firm (Zeng, Li, Zhu, Cai, \& Li, 2013), with marketing competence also being shown to play a mediating role in the relationship between CSR and firm performance (Bai \& Chang, 2015). The interaction effect of CSR and innovation on business performance is also explored, with Costa, Lages, and Hortinha (2015) finding a positive effect of CSR on exploratory innovation. Although studies have found an effect of CSR on financial performance (Cui, Liang, \& Lu, 2015; Munoz et al., 2015), Hou, Liu, Fan, and Wei (2016) find that CSR has more of an influence on operational performance than financial performance, and that environmental CSR is more beneficial for the bottom line than socially oriented CSR.

In this cluster, the concept of legitimacy is often used in conjunction with financialperformance-related arguments (e.g. Aguilera-Caracuel, Guerrero-Villegas, Vidal-Salazar, \& Delgado-Marquez, 2015; Zeng et al., 2013). Legitimacy also plays an important role in foreign markets, where new entrants often engage in host-market CSR to overcome their liability of foreignness (Maruyama \& Wu, 2015). Furthermore, within emerging economies, 
philanthropic behavior is adopted by firms in order to acquire legitimacy with outside stakeholders (Zheng, Luo, \& Maksimov, 2015), demonstrating the use of CSR as a strategic tool. The relationship between CSR and legitimacy from a governmental perspective is also examined, and findings show that CSR is used to gain political legitimacy from the hostmarket government (Marquis, Yin, \& Yang, 2017) and that the CSR disclosures of MNE subsidiaries are used to gain legitimacy and reduce the liability of foreignness (Riaz, Ray, Ray, \& Kumar, 2015).

In other areas relating to the business case of CSR, it has been shown to contribute to value creation (Husted \& Allen, 2009), with responsible supply chain management having the potential to improve relationship commitment between lead firms and their suppliers, as well as improving the sustainability performance of suppliers (Lee, 2016). Further research also highlights that firms tend to adopt a more business case approach to CSR, focusing on market gains rather than on their employees (Cooke \& He, 2010). From a more critical perspective, Labucay (2015) proposes a revision of the business case approach to incorporate both social and economic efficiency.

Studies exploring the antecedents and consequences of CSR also draw upon firm-level attributes that impact upon the overall degree of social responsibility. In the area of labor protection, research has found that state-owned enterprises demonstrate a greater tendency to implement pro-labor protection mechanisms than non-state-owned enterprises (Han \& Zheng, 2016). However, state ownership has also been found to weaken unabsorbed organizational slack and therefore a firm's overall contribution to corporate social performance (Xu, Yang, Quan, \& Lu, 2015). In terms of international diversification, its impact upon firms' CSR behavior remains varied, as firms demonstrate both responsible and irresponsible behavior during such times (Strike, Gao, \& Bansal, 2006). Furthermore, from a leadership perspective, research finds that ethical leadership affects CSR through its moderating effect on firm 
reputation (Zhu, Sun, \& Leung, 2014), with intercultural competencies regarded as important in addressing CSR demands within communities (Miska et al., 2013).

Beyond firm-level characteristics, institutional pressures impact upon the CSR behavior of the firm (Judge, McNatt, \& Xu, 2011; Young \& Makhija, 2014), with evidence showing that institutional differences inherent in liberal (LMEs) and command (CMEs) market economies impacting differently upon firms' CSR behavior (Purdy, Alexander, \& Neill, 2010). Furthermore, findings show that firms from LMEs communicate more regarding CSR than do firms from CMEs (Carrasco-Monteagudo \& Buendia-Martinez, 2013), with the governing environment of a country (whether rules-based or relation-based governance) significantly determining the degree to which firms communicate about their CSR practices (Li, Fetscherin, Alon, Lattemann, \& Yeh, 2010). Li et al. (2010) find that firms from rulesbased countries tend to communicate more on their CSR practices.

Beyond formal institutional factors, informal cultural dynamics and norms impact upon CSR. Evidence demonstrates that a religious atmosphere strengthens CSR (Du, Du, Zeng, Pei, \& Chang, 2016), cultural systems influence social performance (Ioannou \& Serafeim, 2012), human values impact upon overall consumer and entrepreneur perceptions of CSR (Gonzalez-Rodriguez, Diaz-Fernandez, \& Simonetti, 2015), and the cultural context of a firm impacts upon its overall social and environmental responsibility (Lynes \& Andrachuk, 2008). Furthermore, when operating in a host country characterized by strong press and speech freedoms, firms will demonstrate a lesser tendency towards social irresponsibility (Fiaschi, Giuliani, \& Nieri, 2017), and when operating in contexts with high issue salience and stakeholder power, MNEs adopt distinct CSR policies in order to manage their overall legitimacy (Rathert, 2016). Further work depicting host-country impacts upon CSR finds that, when home-country distance - that is, between the MNE headquarters and its 
subsidiaries - is high, the subsidiaries are less likely to engage in CSR (Campbell, Eden, \& Miller, 2012).

Several studies explore the influence of stakeholders on CSR behavior (Judge et al., 2011; Oetzel \& Getz, 2012). Studies address this impact upon managerial perceptions of CSR (Kuznetsov \& Kuznetsova, 2010) and the impacts of primary (internal) and secondary stakeholders, such as consumers (Zhao, Park, \& Zhou, 2014) and subsidiaries (Park, Chidlow, \& Choi, 2014; Park \& Ghauri, 2015). Although subsidiaries can seek to gain autonomy from their parent firm through CSR (Morgenroth \& Luiz, 2017), research shows that the power asserted by the parent firm over its subsidiaries can crowd out local stakeholder voices (Crilly, 2011). Furthermore, shareholder power has been shown to have negative implications for CSR behavior by contributing to CSR suspensions (Liu, Feng, \& Li, 2015). Within the domain of corporate political activity, findings show that firms use corporate diplomacy to engage with external stakeholders (Henisz, 2016). Such behavior can take the form of either overt or covert political activity (Uldam \& Hansen, 2017), with the intensity of this activity also influenced by country- and firm-specific conditions (Holtbrugge, Berg, \& Puck, 2007).

Studies in the category of governance examine the relationship between corporate governance structures and responsible business behavior (e.g. Cuadrado-Ballesteros, Rodriguez-Ariza, \& Garcia-Sanchez, 2015; de Graaf, 2016). When investigating the firmlevel characteristics that shape corporate governance, research finds that, when there is a high proportion of independent directors, CSR disclosures are higher (Cuadrado-Ballesteros et al., 2015). Gallego-Alvarez and Ortas (2017) investigate the impact of community culture upon sustainability reporting, whilst other studies demonstrate that firms from strong collectivist and feminist societies display greater information integration within their disclosures (GarciaSanchez, Rodriguez-Ariza, \& Frias-Aceituno, 2013). Furthermore, studies point to the role of government and the ethical decision-making behavior of auditors in shaping CSR disclosures 
and corporate governance (de Graaf, 2016; Rodgers, 2009). Finally, institutional characteristics are discussed as impacting corporate governance behavior, with international regimes recognized as facilitating accountability in MNEs (Omoteso \& Yusuf, 2017) and standards enforcement mechanisms recognized as increasing the level of CSR reporting in firms (Fortanier, Kolk, \& Pinkse, 2011). When investigating the communication of CSR through company web pages, research finds that the manner in which CSR messages are conveyed varies across different countries (Maignan \& Ralston, 2002), and these differences in CSR reporting can be explained not just by formal institutional drivers but also by traditional informal factors specific to the national context (Ertuna \& Tukel, 2010). Crosslisting leads to better CSR but not governance, and this relationship effect is determined by investor protection regimes (Del Bosco \& Misani, 2016).

With respect to environmental responsibility, we identified studies looking into factors influencing firms' environmental orientation, strategy, and performance (e.g. Leonidou, Fotiadis, Christodoulides, Spyropoulou, \& Katsikeas, 2015), such as knowledge and experience acquired from international operations (Aguilera-Caracuel, Hurtado-Torres, \& Aragon-Correa, 2012), variations in motivations and attitudes towards corporate responsibility across cultures (Furrer et al., 2010; Mueller et al., 2011), and the effect of national institutional and market characteristics on environmental responsibility and sustainable development (e.g. Hartmann \& Uhlenbruck, 2015; Meng, Zeng, Xie, \& Qi, 2016; Wagner, 2015), including stakeholder pressures and preferences in a given country (e.g. Grinstein \& Riefler, 2015; Tatoglu, Bayraktar, Sahadev, Demirbag, \& Glaister, 2014). Further topics are concerned with the impact of international treaties, agreements, and regimes (Rugman \& Kirton, 1998), and how environmental challenges can be used as opportunities for developing capabilities and firm-specific advantages (Kolk \& Pinkse, 2008). 
CSR research further relates to the theme of corporate governance. Despite evidence suggesting that reporting does not necessarily lead to greater company-stakeholder interaction (Barkemeyer, Preuss, \& Lee, 2015), firms seek to acquire legitimacy through corporate environmental disclosures (Hu \& Karbhari, 2015) and social disclosures (Shinkle \& Spencer, 2012). Further evidence finds that increased disclosure of nutritional information may lead to positive CSR behavior (Choi, 2017). When considering the firm-level outcomes, good governance practices can lead to increased profitability (Ngobo \& Fouda, 2012), and firms can improve their company image and reputation by integrating social and financial reporting (Polo \& Vazquez, 2008). Finally, from an external perspective, the adoption of ethical standards by firms within a nation may also have developmental benefits by encouraging FDI in a host market (Robertson, Gilley, \& Street, 2003).

Other sub-themes that have received less attention include 'CSR and brand-related issues' and 'attitudes towards CSR'. Within the sub-theme of CSR and brand-related issues, research finds that firms embed sustainability as a brand differentiation strategy (Gupta et al., 2013). In managing brand reputation, nascent studies have sought to investigate how firms reconcile building a socially responsible brand with selling controversial, harmful products (Gupta, 2016), whereas other studies have shown that, when there is a high host-country distance effect, consumer loyalty and trust in a brand are weakened (Swoboda, Huber, Schuster, \& Hirschmann, 2017). When discussing attitudes towards CSR, studies have explored the views of business professionals (Ralston et al., 2015), managers (Furrer et al., 2010), and consumers (Auger, Devinney, Louviere, \& Burke, 2010; Grinstein \& Riefler, 2015; Hume, 2010), about CSR. 


\subsection{FDI and economic development}

As the label of this cluster suggests, articles can be broadly classified into explicit (e.g. Agbloyor, Gyeke-Dako, Kuipo, \& Abor, 2016; Buckley, 2009) and implicit (e.g. AmankwahAmoah, 2015) explorations of the relationship between FDI and economic development.

Studies dealing with explicit FDI detail its impact on economic development by addressing the benefits that arise from linkages and spillovers (Firth \& Ghauri, 2010; Jindra, Giroud, \& Scott-Kennel, 2009; Lehrer, Asakawa, \& Behnam, 2011; Santangelo, 2009), international ventures (Di Gregorio, Musteen, \& Thomas, 2008), university and industry cooperation (Calori, Melin, Atamer, \& Gustavsson, 2000), investment in public goods through corporate citizenship programs (Bhanji \& Oxley, 2013), and higher employee wages that are implemented to raise income levels (Maksimov, Wang, \& Luo, 2017). Several studies specifically address the impact and/or role of FDI and investment in emerging and developing economies (e.g.Agbloyor et al., 2016; Allred \& Park, 2007; Osabutey \& Okoro, 2015).

Comparative studies often use economic development as a moderating or control variable, or to contextualize a study (Hermes, Smid, \& Yao, 2007; Kandogan, 2014), and thus represent a more indirect treatment of the FDI-economic-development relationship. Studies find that economic development of a nation moderates the relationship between parent-firm intangibles and foreign-affiliate performance (Contractor, Yang, \& Gaur, 2016). Themes emerging in this cluster include the investigation of factors that encourage/discourage FDI (e.g. Ayentimi, Burgess, \& Brown, 2016; Driffield, Jones, \& Crotty, 2013; Osabutey \& Okoro, 2015). Studies addressing economic development as a control variable address its role and that of economic disparity on cross-border acquisitions (Lim \& Lee, 2017) and channel length, which describes the number of intermediaries between manufacturer and consumer (Jaffe \& Yi, 2007). Further studies examine the impact of socio-economic distance (Drogendijk \& Martin, 2015) and human mobility (Gao, Liu, \& Zou, 2013) on outward FDI. Studies dealing 
with economic development as a contextual variable have received relatively significant coverage. A number of studies deal with topics within an emerging/developing-economy

context. Studies explore conflict resolution through firm negotiation (Agbloyor et al., 2016), the HRM practices of emerging market MNEs (EMNEs) in Africa (Xing, Liu, Tarba, \& Cooper, 2016), the impact of patent strength on innovative activity (Allred \& Park, 2007), and the adoption of investment incentive policies to attract FDI in sub-Saharan Africa (SSA) (Ayentimi et al., 2016). Other notable areas of focus include the location choices of firms and location patterns of trade (Suder, Liesch, Inomata, Mihailova, \& Meng, 2015), location pattern differences between foreign-owned and domestic US firms (Shaver, 1998), the location choices of firms from newly industrialized economies (Lei \& Chen, 2011), and the time effect of location choice on the performance of MNEs (Yuan, Pangarkar, \& Wu, 2016).

\subsection{Institutional dynamics and non-market strategies}

Papers in this category are generally concerned with how various institutional dynamics influence the non-market strategies of firms and their degree of responsible business behavior. The NVivo analysis yielded the following sub-themes: (a) the impact of institutional dynamics on the firm; (b) factors shaping corporate governance in different institutional environments and its outcomes; (c) firm responses to institutional voids; and (d) the philanthropic behavior of firms across cultures.

Studies exploring the impact of institutional dynamics upon the firm have addressed the impacts of social values and social justice on firms' innovation (Carrasco-Monteagudo \& Buendia-Martinez, 2013, 2015), legal and cultural characteristics on market financing (Aggarwal \& Goodell, 2010), extra-territorial effects of institutions on firms (Meyer \& Thein, 2014), and non-governmental organizations (NGOs) on MNE transaction costs (Vachani, Doh, \& Teegen, 2009). Research finds that increased political activity and engagement brings benefits for firm performance (Shirodkar \& Mohr, 2015). Other studies addressing the impact 
of institutional factors on the firm address the role of political connectedness in reducing information asymmetries (Chen, Ding, \& Kim, 2010) and improving the performance of mergers and acquisitions (M\&As) as well as influencing their activities (Brockman, Rui, \& Zou, 2013). Evidence also demonstrates that firms that are politically connected are more likely to engage in corporate risk taking (Boubakri, Mansi, \& Saffar, 2013). The notion of connectedness is also explored in reference to the relationships business owners need in order to acquire new business; evidence shows that companies achieve diversification through 'economies' of connectedness (Dieleman \& Sachs, 2008).

Institutional convergence (Adegbite, Amaeshi, \& Nakajima, 2013), informal institutions (Estrin \& Prevezer, 2011), and the ownership structure of a firm (Aguilera \& Crespi-Cladera, 2016; Filatotchev, Zhang, \& Piesse, 2011) have all been shown to have an impact on corporate governance. Other studies have depicted the implementation of good governance mechanisms in weak institutional settings (Adegbite, 2015), in response to pressure to tighten corporate governance (Windsor, 2009).

Regarding institutional voids, firms use CSR as a tool to compensate for them (Baik, Cho, Choi, \& Kang, 2015), with evidence showing there is no definitive business group influence on them (Carney, Van Essen, Estrin, \& Shapiro, 2017).

Philanthropy has been shown to be used as a strategic resource (Cowan, Huang, \& Padmanabhan, 2016) that positively impacts on firm performance (Gao \& Yang, 2016). Market and regulatory uncertainty encourages corporate giving (Gao, Lin, \& Yang, 2017), with further evidence showing that philanthropy is used as tool to mitigate environmentally irresponsible behavior (Du, Chang, Zeng, Du, \& Pei, 2016), and military executives shown to be less likely to use philanthropy illegitimately (Luo, Xiang, \& Zhu, 2017). When discussing the philanthropic behavior of the firm, research indicates that firms with political affiliations 
engage in a higher level of philanthropy (Jia \& Zhang, 2013), and the institutional ownership of a firm increases the level of philanthropy (Song, Gianiodis, \& Li, 2016).

Other studies explore interactions between market and non-market actors (Doh \& Lucea, 2013; Franco, Haase, \& Fernandes, 2014), the impact of global value chains (GVCs) on economic and social upgrading processes (Omoteso \& Yusuf, 2017), and the relationship between institutional characteristics and corruption (Lee, Oh, \& Eden, 2010).

\subsection{Business models and entrepreneurship in developing markets}

Papers in this cluster can broadly be divided into two main themes. The first overarching topic covers micro-level investigations of the role of business in emerging markets' economic development. The second broad topic covers a range of issues connected to social entrepreneurship.

A more fine-grained analysis of each umbrella theme yielded the following subthemes. Micro-level investigations of businesses' developmental role can be broken down into the role of microfinance in enabling business development by fostering the internationalization of micro-enterprises (Mersland, Randoy, \& Strom, 2011) and supporting women borrowers (Aggarwal, Goodell, \& Selleck, 2015), with other studies detailing the performance, profitability, and mission drift of microfinance institutions (Bruton, Khavul, \& Chavez, 2011; Im \& Sun, 2015; Serrano-Cinca \& Gutierrez-Nieto, 2014). Further studies deal with building markets for the poor through the creation of inclusive markets (Acosta, Kim, Melzer, Mendoza, \& Thelen, 2011) and strategies aimed at addressing poverty (Alvarez, Barney, \& Newman, 2015; Si et al., 2015). Social embeddedness is depicted as a capability MNEs consider when entering emerging markets (London \& Hart, 2004) and which they use as a local legitimization strategy (Gifford \& Kestler, 2008). Environment-based issues are also addressed when discussing the environmental orientation of exporting emerging- 
economy SMEs (Chan \& Ma, 2016) and MNE responses to institutional voids, such as climate change (Pinkse \& Kolk, 2012).

Further studies address the factors contributing to enterprise resilience under adverse conditions (Branzei \& Abdelnour, 2010; Sinkovics et al., 2014), with studies on entrepreneurship investigating the internationalization of immigrant entrepreneurs (Sui, Morgan, \& Baum, 2015) and the export orientation of entrepreneurial activity (Terjesen \& Hessels, 2009). Further areas relate to public-private partnerships and collaboration with NGOs (George, Rao-Nicholson, Corbishley, \& Bansal, 2015; Gifford \& Kestler, 2008), criminal enterprises (Gillespie \& McBride, 2013; Wood \& da Costa, 2015), humanitarian logistics (Hirschinger, Moser, Schaefers, \& Hartmann, 2016), social upgrading in GVCs (Khattak, Haworth, Stringer, \& Benson-Rea, 2017; Lee \& Gereffi, 2015), and unionization and collective bargaining (Kuruvilla \& Zhang, 2016).

Social-entrepreneurship-related issues include conceptualization and operationalization efforts (Carraher, Welsh, \& Svilokos, 2016; Mendez-Picazo, RibeiroSoriano, \& Galindo-Martin, 2015; Peredo \& McLean, 2006), responses to institutional challenges (El Ebrashi \& Darrag, 2017), issues surrounding indigenous land rights (Anderson, Dana, \& Dana, 2006), the impact of commercialization on mission drift in social enterprises (Ault, 2016), scaling up and growth-related issues (Ben Letaifa, 2016; Sharir \& Lerner, 2006; Sunduramurthy, Zheng, Musteen, Francis, \& Rhyne, 2016), and the role of institutions in social enterprise development and success (Stephan, Uhlaner, \& Stride, 2015).

\subsection{Corruption}

Studies in this cluster can be divided into two main themes: country-level and firmlevel investigations of corruption. 
Macro-level studies examine topics such as the role of institutions in tackling corruption through institutional laws that reduce bribery (Cuervo-Cazurra, 2008b) and anticorruption agencies that transform corrupt countries (Mao, Wong, \& Peng, 2013). Other topics explore the antecedents and effects of corruption. Findings show that the bribery level of the firm is impacted by the presence of institutional uncertainty (Li, Yao, \& Ahlstrom, 2015) and by the level of state control (Lee et al., 2010). Further evidence shows that corruption levels are higher in collectivist societies (Husted, 1999; Zheng, El Ghoul, Guedhami, \& Kwok, 2013). However, other research has found that, when there is greater access to information through information and communication technology (ICT), the level of national corruption is decreased (DiRienzo, Das, Cort, \& Burbridge, 2007).

Studies addressing the effects of corruption deal with its impact on FDI (CuervoCazurra, 2006, 2008a; Demirbag, Tatoglu, \& Glaister, 2010; Habib \& Zurawicki, 2002; Mudambi, Navarra, \& Delios, 2013), with evidence commonly suggesting a negative influence (Cuervo-Cazurra, 2006; Demirbag, McGuinnness, Wood, \& Bayyurt, 2015). Research finds that the level of national corruption influences the entry-strategy choice of a firm (Duanmu, 2011). Although evidence has found that very corrupt countries attract greater foreign portfolio investment than moderately corrupt countries (Jain, Kuvvet, \& Pagano, 2017), local corruption may present a market entry barrier (Weitzel \& Berns, 2006) and harm human development (Akhter, 2004). Firm-level corruption has been shown to lead to operational inefficiencies (Habib \& Zurawicki, 2002), lower creation rates (Jimenez, PucheRegaliza, Jimenez-Eguizabal, \& Alon, 2017), and reduced subsidiary profitability (Lee \& Hong, 2012). Other work has shown that managerial control increases the incidence of firmlevel bribery (Chen, Cullen, \& Parboteeah, 2015), with bribery damaging firm growth in SMEs more than MNEs (Zhou \& Peng, 2012). 
Studies conceptualizing and operationalizing corruption detail its historic roots (Rowley \& Oh, 2016b), provide a critical assessment of it in order to extend theories on the topic (Cuervo-Cazurra, 2016), depict its negative consequences (Rowley \& Andrews, 2017), and review existing literature on its antecedents and effects (Judge et al., 2011).

Other studies detailing firm irresponsibility have explored why firms evade tax (Gokalp, Lee, \& Peng, 2017) and highlighted how product recalls damage corporate credibility (Fetscherin, Voss, \& Gugler, 2010).

\subsection{Implementation of non-market strategies}

One strand within this cluster includes attempts to theoretically integrate societal failures, CSR, and other non-market strategies (Buckley \& Boddewyn, 2015, 2016; Devinney, McGahan, \& Zollo, 2013). Another group of papers explores the use of non-market strategies to gain legitimacy and improve firm performance, through environmental labelling (Wang, Cui, \& Liang, 2015), the offering of socially valuable goods and services (Darendeli \& Hill, 2016), the development of new entrepreneurial technology (de Lange, 2016), and the use of reporting (Marano, Tashman, \& Kostova, 2017) and CSR certifications (Husted, Montiel, \& Christmann, 2016). Strategies aimed at tackling child labor (Kolk \& Van Tulder, 2004) and reducing greenhouse gas emissions (Duc \& Ba, 2017) emerge at the more critical end of the spectrum. These studies are situated alongside other work discussing corporate social irresponsibility and dubious behavior (Fiaschi et al., 2017; Myers, 1999), product recalls due to design flaws (Beamish \& Bapuji, 2008), and the impact of gray-market activity on strategic and economic performance (Myers, 1999).

Further studies addressing firm ownership structures examine the role of cooperatives in facilitating corporate diversity and sustainability and as an alternative form of corporate organizing post the 2008 financial crisis (Michie \& Rowley, 2014; Rowley \& Michie, 2014). 
Findings also demonstrate that institutional investors with a long-term orientation bring about increased CSR rankings (Boubaker, Chourou, Himick, \& Saadi, 2017) and further work depicts the negative impact of oligarchic control in increasing corruption and impeding economic growth (Fogel, 2006).

\subsection{Under-represented topics in IB}

Studies in this cluster can be assigned to one of three categories. The majority of the papers in the first category are related to MNE-NGO collaborations (e.g. Herlin \& Solitander, 2017; Marano \& Tashman, 2012), and NGOs' campaigning strategies (Ivanova, 2016; Reis \& Guedes, 2017).

The common denominator in the second category is the attempt to raise critical issues. Jagannathan, Selvaraj, and Joseph (2016) deliberate as to how IB creates and maintains inequalities for the marginalized in developing countries. Andersson and Calvano (2015) analyze how the globally mobile elite promote the perception that market-driven solutions are better suited to tackling social problems than national governments and civil society. Chakraborty, Saha, and Jammulamadaka (2017) examine why the voices of Third World NGOs are often not heard in global discourses. Srikantia (2016) discusses the structural violence of globalization, while Yolles (2007) models the pathologies of social collectives, pointing out sociopathic tendencies of corporations and governments.

Studies in the third category are diverse. They discuss a range of ethics- and CSRrelated themes, from the benefits of developing ethical capabilities (Buller \& McEvoy, 1999), to how MNEs can improve their CSR outcomes through specific language resources (Selmier, Newenham-Kahindi, \& Oh, 2015), to taking stock of 50 years of IB research on socialresponsibility-related issues in the discipline's two most important journals, JWB and JIBS (Kolk, 2016). 


\section{Concluding remarks}

This chapter has attempted to provide an overview of the main themes and sub-themes connected to the various forms and degrees of firm-related responsibility discussed in the IB literature. Our stock-taking exercise has yielded the following overall insights. While research on the positive side of the spectrum of responsibility is on the rise, the negative side is comparatively under-represented in the IB literature. Furthermore, a large proportion of studies in our sample look at macro-level relationships. A notable example is the impact of FDI on economic development. In connection with this theme, our investigation has also uncovered that IB studies frequently use economic development as a context variable. Thus, conclusions about the nature of developmental impact of firm activities are more implicit than explicit. As a consequence, there is a need for more micro-level studies documenting the ways businesses can contribute to local, regional, national, and international economic development.

Similarly, research on corruption has been more concerned with country-level analyses than with explicit firm engagement in corruption-related activities including bribery, blackmail, and other criminal activities. Further dimensions of irresponsible firm behavior (cf. Tillmann et al., 2008), including human rights violations, tax evasion, the manufacturing and distribution of harmful products, pollution, etc., also need more attention. Finally, there is room for more studies with a critical and provocative stance to direct attention towards current blind spots in IB research. Relatedly, scholars who want to dedicate themselves to uncovering and unpacking such blind spots are well advised to look to neighboring disciplines for inspiration, such as development studies, political science, and economic geography.

Like any study, our chapter also has limitations. Despite our effort to address what we perceived as shortcomings in other review papers on this topic, no search strategy is perfect. To ensure that no papers are overlooked, future studies may wish to go through all the articles published in the selected journals. Furthermore, as outlined in the methods section, we 
omitted two IB journals because they were not included in the Web of Science database.

Future research may wish to extend the search to all 16 journals. We would also like to note, that using these 16 journals as a proxy for the universe of IB publications introduces the problem of not capturing the work of IB scholars published in other journals. Lastly, due to space limitations we are not able to provide the reader with a more comprehensive list of future research avenues. However, we have attempted to provide a synthesis of existing topics and findings. This, together with Table 3.2, offers a starting point for the identification of future research questions.

\section{References}

Acosta, P., Kim, N., Melzer, I., Mendoza, R. U., \& Thelen, N. (2011). Business and human development in the base of the pyramid: Exploring challenges and opportunities with market heat maps. Journal of World Business, 46(1), 50-60. doi: 10.1016/j.jwb.2010.05.017

Adegbite, E. (2015). Good corporate governance in nigeria: Antecedents, propositions and peculiarities. International Business Review, 24(2), 319-330. doi: 10.1016/j.ibusrev.2014.08.004

Adegbite, E., Amaeshi, K., \& Nakajima, C. (2013). Multiple influences on corporate governance practice in nigeria: Agents, strategies and implications. International Business Review, 22(3), 524-538. doi: 10.1016/j.ibusrev.2012.07.006

Agbloyor, E. K., Gyeke-Dako, A., Kuipo, R., \& Abor, J. Y. (2016). Foreign direct investment and economic growth in ssa: The role of institutions. Thunderbird International Business Review, 58(5), 479-497. doi: 10.1002/tie.21791

Aggarwal, R., \& Goodell, J. W. (2010). Financial markets versus institutions in european countries: Influence of culture and other national characteristics. International Business Review, 19(5), 502-520. doi: 10.1016/j.ibusrev.2009.07.010

Aggarwal, R., Goodell, J. W., \& Selleck, L. J. (2015). Lending to women in microfinance: Role of social trust. International Business Review, 24(1), 55-65. doi: 10.1016/j.ibusrev.2014.05.008

Aguilera-Caracuel, J., Guerrero-Villegas, J., Vidal-Salazar, M. D., \& Delgado-Marquez, B. L. (2015). International cultural diversification and corporate social performance in multinational enterprises: The role of slack financial resources. Management International Review, 55(3), 323-353. doi: 10.1007/s11575-014-0225-4

Aguilera-Caracuel, J., Hurtado-Torres, N. E., \& Aragon-Correa, J. (2012). Does international experience help firms to be green? A knowledge-based view of how international experience and organisational learning influence proactive environmental strategies. International Business Review, 21(5), 847-861. doi: 10.1016/j.ibusrev.2011.09.009

Aguilera, R. V., \& Crespi-Cladera, R. (2016). Global corporate governance: On the relevance of firms' ownership structure. Journal of World Business, 51(1), 50-57. doi: 10.1016/j.jwb.2015.10.003 
Akhter, S. H. (2004). Is globalization what it's cracked up to be? Economic freedom, corruption, and human development. Journal of World Business, 39(3), 283-295. doi: 10.1016/j.jwb.2004.04.007

Al-Khatib, J. A., Malshe, A., \& AbdulKader, M. (2008). Perception of unethical negotiation tactics: A comparative study of us and saudi managers. International Business Review, 17(1), 78-102. doi: 10.1016/j.ibusrev.2007.12.004

Allred, B. B., \& Park, W. G. (2007). Patent rights and innovative activity: Evidence from national and firm-level data. Journal of International Business Studies, 38(6), 878-900. doi: 10.1057/palgrave.jibs. 8400306

Alvarez, S. A., Barney, J. B., \& Newman, A. M. B. (2015). The poverty problem and the industrialization solution. Asia Pacific Journal of Management, 32(1), 23-37. doi: 10.1007/s10490-014-9397-5

Amankwah-Amoah, J. (2015). Solar energy in sub-saharan africa: The challenges and opportunities of technological leapfrogging. Thunderbird International Business Review, 57(1), 15-31. doi: 10.1002/tie.21677

Ananthram, S., \& Chan, C. (2016). Religiosity, spirituality and ethical decision-making: Perspectives from executives in indian multinational enterprises. Asia Pacific Journal of Management, 33(3), 843-880. doi: 10.1007/s10490-016-9460-5

Anderson, R. B., Dana, L. P., \& Dana, T. E. (2006). Indigenous land rights, entrepreneurship, and economic development in canada: "Opting-in" to the global economy. Journal of World Business, 41(1), 45-55. doi: 10.1016/j.jwb.2005.10.005

Andersson, L., \& Calvano, L. (2015). Perceived mobility of impact: Global elites and the bono effect. Critical Perspectives on International Business, 11(2), 122-136. doi: 10.1108/cpoib-10-2012-0046

Auger, P., Devinney, T. M., Louviere, J. J., \& Burke, P. F. (2010). The importance of social product attributes in consumer purchasing decisions: A multi-country comparative study. International Business Review, 19(2), 140-159. doi:

10.1016/j.ibusrev.2009.10.002

Ault, J. K. (2016). An institutional perspective on the social outcome of entrepreneurship: Commercial microfinance and inclusive markets. Journal of International Business Studies, 47(8), 951-967. doi: 10.1057/jibs.2016.18

Ayentimi, D. T., Burgess, J., \& Brown, K. (2016). Developing effective local content regulations in sub-sahara africa the need for more effective policy alignment. Multinational Business Review, 24(4), 354-374. doi: 10.1108/mbr-08-2015-0040

Bai, X., \& Chang, J. (2015). Corporate social responsibility and firm performance: The mediating role of marketing competence and the moderating role of market environment. Asia Pacific Journal of Management, 32(2), 505-530. doi: 10.1007/s10490-015-9409-0

Baik, B., Cho, K., Choi, W., \& Kang, J. K. (2015). The role of institutional environments in cross-border mergers: A perspective from bidders' earnings management behavior. Management International Review, 55(5), 615-646. doi: 10.1007/s11575-015-0249-4

Barkemeyer, R., Preuss, L., \& Lee, L. (2015). On the effectiveness of private transnational governance regimes-evaluating corporate sustainability reporting according to the global reporting initiative. Journal of World Business, 50(2), 312-325. doi: 10.1016/j.jwb.2014.10.008

Beamish, P. W., \& Bapuji, H. (2008). Toy recalls and china: Emotion vs. Evidence. Management and Organization Review, 4(2), 197-209. doi: 10.1111/j.17408784.2008.00105.x 
Ben Letaifa, S. (2016). How social entrepreneurship emerges, develops and internationalises during political and economic transitions. European Journal of International Management, 10(4), 455-466. doi: 10.1504/ejim.2016.077424

Bhanji, Z., \& Oxley, J. E. (2013). Overcoming the dual liability of foreignness and privateness in international corporate citizenship partnerships. Journal of International Business Studies, 44(4), 290-311. doi: 10.1057/jibs.2013.8

Bitros, G. C., \& Karayiannis, A. D. (2010). Entrepreneurial morality: Some indications from greece. European Journal of International Management, 4(4), 333-361. doi: 10.1504/ejim.2010.033606

Boubaker, S., Chourou, L., Himick, D., \& Saadi, S. (2017). It's about time! The influence of institutional investment horizon on corporate social responsibility. Thunderbird International Business Review, 59(5), 571-594. doi: 10.1002/tie.21910

Boubakri, N., Mansi, S. A., \& Saffar, W. (2013). Political institutions, connectedness, and corporate risk-taking. Journal of International Business Studies, 44(3), 195-215. doi: 10.1057/jibs.2013.2

Bramming, P., \& Johnsen, R. (2011). Love will tear us apart - transformational leadership and love in a call centre. European Journal of International Management, 5(1), 80-95. doi: 10.1504/ejim.2011.037784

Branzei, O., \& Abdelnour, S. (2010). Another day, another dollar: Enterprise resilience under terrorism in developing countries. Journal of International Business Studies, 41(5), 804-825. doi: 10.1057/jibs.2010.6

Brockman, P., Rui, O. M., \& Zou, H. (2013). Institutions and the performance of politically connected m\&as. Journal of International Business Studies, 44(8), 833-852. doi: 10.1057/jibs.2013.37

Bruton, G. D., Khavul, S., \& Chavez, H. (2011). Microlending in emerging economies: Building a new line of inquiry from the ground up. Journal of International Business Studies, 42(5), 718-739. doi: 10.1057/jibs.2010.58

Buckley, P. J. (2002). Is the international business research agenda running out of steam? Journal of International Business Studies, 33(2), 365-373. doi: 10.1057/palgrave.jibs.8491021

Buckley, P. J. (2009). The impact of the global factory on economic development. Journal of World Business, 44(2), 131-143. doi: 10.1016/j.jwb.2008.05.003

Buckley, P. J., \& Boddewyn, J. J. (2015). The internalization of societal failures by multinational enterprises. Multinational Business Review, 23(3), 170-+. doi: 10.1108/mbr-08-2014-0041

Buckley, P. J., \& Boddewyn, J. J. (2016). A manifesto for the widening of internalisation theory, being a reply to hillemann and verbeke. Multinational Business Review, 24(1), 2-7. doi: 10.1108/mbr-11-2015-0055

Buckley, P. J., Doh, J. P., \& Benischke, M. H. (2017). Towards a renaissance in international business research? Big questions, grand challenges, and the future of ib scholarship. Journal of International Business Studies. doi: 10.1057/s41267-017-0102-z

Buller, P. F., \& McEvoy, G. M. (1999). Creating and sustaining ethical capability in the multi-national corporation. Journal of World Business, 34(4), 326-343. doi: 10.1016/s1090-9516(99)00022-x

Calori, R., Melin, L., Atamer, T., \& Gustavsson, P. (2000). Innovative international strategies. Journal of World Business, 35(4), 333-354. doi: 10.1016/s1090-9516(00)00042-0

Campbell, J. T., Eden, L., \& Miller, S. R. (2012). Multinationals and corporate social responsibility in host countries: Does distance matter? Journal of International Business Studies, 43(1), 84-106. doi: 10.1057/jibs.2011.45 
Carney, M., Van Essen, M., Estrin, S., \& Shapiro, D. (2017). Business group prevalence and impact across countries and over time what can we learn from the literature? Multinational Business Review, 25(1), 52-76. doi: 10.1108/mbr-10-2016-0037

Carraher, S. M., Welsh, D. H. B., \& Svilokos, A. (2016). Validation of a measure of social entrepreneurship. European Journal of International Management, 10(4), 386-402. doi: 10.1504/ejim.2016.077421

Carrasco-Monteagudo, I., \& Buendia-Martinez, I. (2013). Corporate social responsibility: A crossroad between changing values, innovation and internationalisation. European Journal of International Management, 7(3), 295-314. doi: 10.1504/ejim.2013.054327

Carrasco-Monteagudo, I., \& Buendia-Martinez, I. (2015). Social justice, entrepreneurship and innovation. European Journal of International Management, 9(5), 635-647. doi: 10.1504/ejim.2015.071546

Chakraborty, K., Saha, B., \& Jammulamadaka, N. (2017). Where silence speaks-insights from third world ngos. Critical Perspectives on International Business, 13(1), 38-53. doi: 10.1108/cpoib-03-2015-0012

Chan, R. Y. K., \& Ma, K. H. Y. (2016). Environmental orientation of exporting smes from an emerging economy: Its antecedents and consequences. Management International Review, 56(5), 597-632. doi: 10.1007/s11575-016-0280-0

Chen, C. C., Unal, A. F., Leung, K., \& Xin, K. R. (2016). Group harmony in the workplace: Conception, measurement, and validation. Asia Pacific Journal of Management, 33(4), 903-934. doi: 10.1007/s 10490-016-9457-0

Chen, C. J. P., Ding, Y. A., \& Kim, C. (2010). High-level politically connected firms, corruption, and analyst forecast accuracy around the world. Journal of International Business Studies, 41(9), 1505-1524. doi: 10.1057/jibs.2010.27

Chen, C. W., Cullen, J. B., \& Parboteeah, K. P. (2015). Are manager-controlled firms more likely to bribe than shareholder-controlled firms: A cross-cultural analysis. Management and Organization Review, 11(2), 343-365. doi: 10.1017/mor.2015.16

Chen, D., Newburry, W., \& Park, S. H. (2009). Improving sustainability: An international evolutionary framework. Journal of International Management, 15(3), 317-327. doi: 10.1016/j.intman.2008.08.003

Choi, J. (2017). The effectiveness of nutritional information on foodservice companies' corporate social responsibility. Asia Pacific Business Review, 23(1), 44-62. doi: 10.1080/13602381.2015.1104820

Collings, D. G., Scullion, H., \& Morley, M. J. (2007). Changing patterns of global staffing in the multinational enterprise: Challenges to the conventional expatriate assignment and emerging alternatives. Journal of World Business, 42(2), 198-213. doi: 10.1016/j.jwb.2007.02.005

Contractor, F., Yang, Y., \& Gaur, A. S. (2016). Firm-specific intangible assets and subsidiary profitability: The moderating role of distance, ownership strategy and subsidiary experience. Journal of World Business, 51(6), 950-964. doi:

10.1016/j.jwb.2016.09.002

Cooke, F. L., \& He, Q. L. (2010). Corporate social responsibility and hrm in china: A study of textile and apparel enterprises. Asia Pacific Business Review, 16(3), 355-376. doi: $10.1080 / 13602380902965558$

Cooke, F. L., \& Saini, D. S. (2015). From legalism to strategic hrm in india? Grievance management in transition. Asia Pacific Journal of Management, 32(3), 619-643. doi: 10.1007/s 10490-015-9417-0

Costa, C., Lages, L. F., \& Hortinha, P. (2015). The bright and dark side of csr in export markets: Its impact on innovation and performance. International Business Review, 24(5), 749-757. doi: 10.1016/j.ibusrev.2015.01.008 
Cowan, A., Huang, C. H., \& Padmanabhan, P. (2016). Why do some us manufacturing and service firms with international operations choose to give internationally whereas others opt to give only in the united states? International Business Review, 25(1), 408418. doi: 10.1016/j.ibusrev.2015.07.001

Crilly, D. (2011). Predicting stakeholder orientation in the multinational enterprise: A midrange theory. Journal of International Business Studies, 42(5), 694-717. doi: $10.1057 /$ jibs. 2010.57

Cuadrado-Ballesteros, B., Rodriguez-Ariza, L., \& Garcia-Sanchez, I. M. (2015). The role of independent directors at family firms in relation to corporate social responsibility disclosures. International Business Review, 24(5), 890-901. doi: 10.1016/j.ibusrev.2015.04.002

Cuervo-Cazurra, A. (2006). Who cares about corruption? Journal of International Business Studies, 37(6), 807-822. doi: 10.1057/palgrave.jibs.8400223

Cuervo-Cazurra, A. (2008a). Better the devil you don't know: Types of corruption and fdi in transition economies. Journal of International Management, 14(1), 12-27. doi: 10.1016/j.intman.2007.02.003

Cuervo-Cazurra, A. (2008b). The effectiveness of laws against bribery abroad. Journal of International Business Studies, 39(4), 634-651. doi: 10.1057/palgrave.jibs. 8400372

Cuervo-Cazurra, A. (2016). Corruption in international business. Journal of World Business, 51(1), 35-49. doi: 10.1016/j.jwb.2015.08.015

Cui, Z. Y., Liang, X. Y., \& Lu, X. W. (2015). Prize or price? Corporate social responsibility commitment and sales performance in the chinese private sector. Management and Organization Review, 11(1), 25-44. doi: 10.1111/more.12033

Darendeli, I. S., \& Hill, T. L. (2016). Uncovering the complex relationships between political risk and mne firm legitimacy: Insights from libya. Journal of International Business Studies, 47(1), 68-92. doi: 10.1057/jibs.2015.27

de Graaf, F. J. (2016). Corporate social responsibility, governance and stakeholders: A bank in the upbeat of the crisis. Critical Perspectives on International Business, 12(4), 388412. doi: 10.1108/cpoib-11-2013-0048

de Lange, D. E. (2016). Legitimation strategies for clean technology entrepreneurs facing institutional voids in emerging economies. Journal of International Management, 22(4), 403-415. doi: 10.1016/j.intman.2016.06.002

Del Baldo, M. (2013). Stakeholders' management approach in italian 'territorial' companies loccioni group and the 'land of values - lov' project. European Journal of International Management, 7(2), 225-246. doi: 10.1504/ejim.2013.052835

Del Bosco, B., \& Misani, N. (2016). The effect of cross-listing on the environmental, social, and governance performance of firms. Journal of World Business, 51(6), 977-990. doi: 10.1016/j.jwb.2016.08.002

Demirbag, M., McGuinnness, M., Wood, G., \& Bayyurt, N. (2015). Context, law and reinvestment decisions: Why the transitional periphery differs from other post-state socialist economies. International Business Review, 24(6), 955-965. doi: 10.1016/j.ibusrev.2015.03.003

Demirbag, M., Tatoglu, E., \& Glaister, K. W. (2010). Institutional and transaction cost influences on partnership structure of foreign affiliates. Management International Review, 50(6), 709-745. doi: 10.1007/s11575-010-0055-y

Devinney, T. M., McGahan, A. M., \& Zollo, M. (2013). A research agenda for global stakeholder strategy. Global Strategy Journal, 3(4), 325-337. doi: 10.1111/j.20425805.2013.01066.x 
Di Gregorio, D., Musteen, M., \& Thomas, D. E. (2008). International new ventures: The cross-border nexus of individuals and opportunities. Journal of World Business, 43(2), 186-196. doi: 10.1016/j.jwb.2007.11.013

Dieleman, M., \& Sachs, W. M. (2008). Economies of connectedness: Concept and application. Journal of International Management, 14(3), 270-285. doi: 10.1016/j.intman.2007.11.002

DiRienzo, C. E., Das, J., Cort, K. T., \& Burbridge, J. (2007). Corruption and the role of information. Journal of International Business Studies, 38(2), 320-332. doi: 10.1057 palgrave.jibs.8400262

Doh, J. P., \& Lucea, R. (2013). So close yet so far: Intergrating global strategy and non market research Global Strategy Journal, 3(2), 171-194. doi: 10.1111/j.20425805.2013.01053.x

Driffield, N., Jones, C., \& Crotty, J. (2013). International business research and risky investments, an analysis of fdi in conflict zones. International Business Review, 22(1), 140-155. doi: 10.1016/j.ibusrev.2012.03.001

Drogendijk, R., \& Martin, O. M. (2015). Relevant dimensions and contextual weights of distance in international business decisions: Evidence from spanish and chinese outward fdi. International Business Review, 24(1), 133-147. doi: 10.1016/j.ibusrev.2014.07.003

Du, X. Q., Chang, Y. Y., Zeng, Q., Du, Y. J., \& Pei, H. M. (2016). Corporate environmental responsibility (cer) weakness, media coverage, and corporate philanthropy: Evidence from china. Asia Pacific Journal of Management, 33(2), 551-581. doi: 10.1007/s10490-015-9449-5

Du, X. Q., Du, Y. J., Zeng, Q., Pei, H. M., \& Chang, Y. Y. (2016). Religious atmosphere, law enforcement, and corporate social responsibility: Evidence from china. Asia Pacific Journal of Management, 33(1), 229-265. doi: 10.1007/s10490-015-9441-0

Duanmu, J. L. (2011). The effect of corruption distance and market orientation on the ownership choice of mnes: Evidence from china. Journal of International Management, 17(2), 162-174. doi: 10.1016/j.intman.2011.01.003

Dubinsky, A. J., Jolson, M. A., Kotabe, M., \& Lim, C. U. (1991). A cross-national investigation of industrial salespeople ethical perceptions. Journal of International Business Studies, 22(4), 651-670. doi: 10.1057/palgrave.jibs.8490318

Duc, B. H., \& Ba, K. D. (2017). Business responses to climate change: Strategies for reducing greenhouse gas emissions in vietnam. Asia Pacific Business Review, 23(4), 596-620. doi: 10.1080/13602381.2016.1212557

Egri, C. P., \& Ralston, D. A. (2008). Corporate responsibility: A review of international management research from 1998 to 2007. Journal of International Management, 14(4), 319-339. doi: https://doi.org/10.1016/j.intman.2007.09.003

El Ebrashi, R., \& Darrag, M. (2017). Social entrepreneurs' strategies for addressing institutional voids in developing markets. European Journal of International Management, 11(3), 325-346. doi: 10.1504/ejim.2017.10004236

Ertuna, B., \& Tukel, A. (2010). Traditional versus international influences: Csr disclosures in turkey. European Journal of International Management, 4(3), 273-289.

Estrin, S., \& Prevezer, M. (2011). The role of informal institutions in corporate governance: Brazil, russia, india, and china compared. Asia Pacific Journal of Management, 28(1), 41-67. doi: 10.1007/s 10490-010-9229-1

Fetscherin, M., Voss, H., \& Gugler, P. (2010). 30 years of foreign direct investment to china: An interdisciplinary literature review. International Business Review, 19(3), 235-246. doi: 10.1016/j.ibusrev.2009.12.002 
Fiaschi, D., Giuliani, E., \& Nieri, F. (2017). Overcoming the liability of origin by doing noharm: Emerging country firms' social irresponsibility as they go global. Journal of World Business, 52(4), 546-563. doi: 10.1016/j.jwb.2016.09.001

Filatotchev, I., Zhang, X. X., \& Piesse, J. (2011). Multiple agency perspective, family control, and private information abuse in an emerging economy. Asia Pacific Journal of Management, 28(1), 69-93. doi: 10.1007/s10490-010-9220-х

Firth, R., \& Ghauri, P. N. (2010). Multinational enterprise acquisitions in emerging markets: Linkage effects on local firms. European Journal of International Management, 4(12), 135-162.

Fogel, K. (2006). Oligarchic family control, social economic outcomes, and the quality of government. Journal of International Business Studies, 37(5), 603-622. doi: 10.1057/palgrave.jibs.8400213

Forsyth, D. R., \& O'Boyle, E. H. (2011). Rules, standards, and ethics: Relativism predicts cross-national differences in the codification of moral standards. International Business Review, 20(3), 353-361. doi: 10.1016/j.ibusrev.2010.07.008

Fortanier, F., Kolk, A., \& Pinkse, J. (2011). Harmonization in csr reporting mnes and global csr standards. Management International Review, 51(5), 665-696. doi: 10.1007/s11575-011-0089-9

Franco, M., Haase, H., \& Fernandes, A. (2014). The influence of academic staff's personal and professional characteristics on the decision to cooperate with industry. European Journal of International Management, 8(3), 293-309. doi: 10.1504/ejim.2014.060770

Franke, G. R., \& Richey, R. G. (2010). Improving generalizations from multi-country comparisons in international business research. Journal of International Business Studies, 41(8), 1275-1293. doi: 10.1057/jibs.2010.21

Froese, F. J. (2013). Work values of the next generation of business leaders in shanghai, tokyo, and seoul. Asia Pacific Journal of Management, 30(1), 297-315. doi: 10.1007/s10490011-9271-7

Furrer, O., Egri, C. P., Ralston, D. A., Danis, W., Reynaud, E., Naoumova, I., . . FurrerPerrinjaquet, A. (2010). Attitudes toward corporate responsibilities in western europe and in central and east europe. Management International Review, 50(3), 379-398. doi: $10.1007 / \mathrm{s} 11575-010-0034-3$

Gallego-Alvarez, I., \& Ortas, E. (2017). Corporate environmental sustainability reporting in the context of national cultures: A quantile regression approach. International Business Review, 26(2), 337-353. doi: 10.1016/j.ibusrev.2016.09.003

Gao, L., Liu, X. H., \& Zou, H. (2013). The role of human mobility in promoting chinese outward fdi: A neglected factor? International Business Review, 22(2), 437-449. doi: 10.1016/j.ibusrev.2012.06.001

Gao, Y. Q., Lin, Y. L., \& Yang, H. B. (2017). What's the value in it? Corporate giving under uncertainty. Asia Pacific Journal of Management, 34(1), 215-240. doi: 10.1007/s10490-016-9478-8

Gao, Y. Q., \& Yang, H. B. (2016). Do employees support corporate philanthropy? Evidence from chinese listed companies. Management and Organization Review, 12(4), 747768. doi: $10.1017 /$ mor.2015.52

Garcia-Sanchez, I. M., Rodriguez-Ariza, L., \& Frias-Aceituno, J. V. (2013). The cultural system and integrated reporting. International Business Review, 22(5), 828-838. doi: 10.1016/j.ibusrev.2013.01.007

Gatrell, C. J., \& Cooper, C. L. (2008). Work-life balance: Working for whom? European Journal of International Management, 2(1), 71-86. doi: 10.1504/ejim.2008.016929

George, G., Rao-Nicholson, R., Corbishley, C., \& Bansal, R. (2015). Institutional entrepreneurship, governance, and poverty: Insights from emergency medical response 
servicesin india. Asia Pacific Journal of Management, 32(1), 39-65. doi: 10.1007/s10490-014-9377-9

Gifford, B., \& Kestler, A. (2008). Toward a theory of local legitimacy by mnes in developing nations: Newmont mining and health sustainable development in peru. Journal of International Management, 14(4), 340-352. doi: 10.1016/j.intman.2007.09.005

Gillespie, K., \& McBride, J. B. (2013). Counterfeit smuggling: Rethinking paradigms of diaspora investment and trade facilitation. Journal of International Management, 19(1), 66-81. doi: 10.1016/j.intman.2012.08.001

Goergen, M., Brewster, C., \& Wood, G. (2013). The effects of the national setting on employment practice: The case of downsizing. International Business Review, 22(6), 1051-1067. doi: 10.1016/j.ibusrev.2013.02.001

Gokalp, O. N., Lee, S. H., \& Peng, M. W. (2017). Competition and corporate tax evasion: An institution-based view. Journal of World Business, 52(2), 258-269. doi: 10.1016/j.jwb.2016.12.006

Gomes, E., Cohen, M., \& Mellahi, K. (2011). When two african cultures collide: A study of interactions between managers in a strategic alliance between two african organizations. Journal of World Business, 46(1), 5-12. doi: 10.1016/j.jwb.2010.05.012

Gonzalez-Rodriguez, M. R., Diaz-Fernandez, M. C., \& Simonetti, B. (2015). The social, economic and environmental dimensions of corporate social responsibility: The role played by consumers and potential entrepreneurs. International Business Review, 24(5), 836-848. doi: 10.1016/j.ibusrev.2015.03.002

Grinstein, A., \& Riefler, P. (2015). Citizens of the (green) world? Cosmopolitan orientation and sustainability. Journal of International Business Studies, 46(6), 694-714. doi: 10.1057/jibs.2015.1

Gupta, S. (2016). A conceptual framework that identifies antecedents and consequences of building socially responsible international brands. Thunderbird International Business Review, 58(3), 225-237. doi: 10.1002/tie.21732

Gupta, S., Czinkota, M., \& Melewar, T. C. (2013). Embedding knowledge and value of a brand into sustainability for differentiation. Journal of World Business, 48(3), 287-296. doi: 10.1016/j.jwb.2012.07.013

Gupta, S., \& Kumar, V. (2013). Sustainability as corporate culture of a brand for superior performance. Journal of World Business, 48(3), 311-320. doi: 10.1016/j.jwb.2012.07.015

Habib, M., \& Zurawicki, L. (2002). Corruption and foreign direct investment. Journal of International Business Studies, 33(2), 291-307. doi: 10.1057/palgrave.jibs.8491017

Han, Y., \& Zheng, E. Y. (2016). Why firms perform differently in corporate social responsibility? Firm ownership and the persistence of organizational imprints. Management and Organization Review, 12(3), 605-629. doi: 10.1017/mor.2016.9

Hartmann, J., \& Uhlenbruck, K. (2015). National institutional antecedents to corporate environmental performance. Journal of World Business, 50(4), 729-741. doi: 10.1016/j.jwb.2015.02.001

Henisz, W. J. (2016). The dynamic capability of corporate diplomacy. Global Strategy Journal, 6(3), 183-196. doi: 10.1002/gsj.1121

Herlin, H., \& Solitander, N. (2017). Corporate social responsibility as relief from responsibility npo legitimizations for corporate partnerships in contested terrains. Critical Perspectives on International Business, 13(1), 2-22. doi: 10.1108/cpoib-042015-0013

Hermes, N., Smid, P., \& Yao, L. (2007). Capital budgeting practices: A comparative study of the netherlands and china. International Business Review, 16(5), 630-654. doi: 10.1016/j.ibusrev.2007.05.002 
Hirschinger, M., Moser, R., Schaefers, T., \& Hartmann, E. (2016). No vehicle means no aida paradigm change for the humanitarian logistics business model. Thunderbird International Business Review, 58(5), 373-384. doi: 10.1002/tie.21745

Hofstede, G. (2009). Business goals for a new world order: Beyond growth, greed and quarterly results. Asia Pacific Business Review, 15(4), 481-488. doi: 10.1080/13602380903102029

Holtbrugge, D., Berg, N., \& Puck, J. F. (2007). To bribe or to convince? Political stakeholders and political activities in german multinational corporations. International Business Review, 16(1), 47-67. doi: 10.1016/j.ibusrev.2006.11.001

Holtbrügge, D., \& Dögl, C. (2012). How international is corporate environmental responsibility? A literature review. Journal of International Management, 18(2), 180195. doi: https://doi.org/10.1016/j.intman.2012.02.001

Hou, M. J., Liu, H., Fan, P. H., \& Wei, Z. L. (2016). Does csr practice pay off in east asian firms? A meta-analytic investigation. Asia Pacific Journal of Management, 33(1), 195-228. doi: 10.1007/s10490-015-9431-2

$\mathrm{Hu}, \mathrm{Y}$. Y., \& Karbhari, Y. (2015). Incentives and disincentives of corporate environmental disclosure: Evidence from listed companies in china and malaysia. Thunderbird International Business Review, 57(2), 143-161. doi: 10.1002/tie.21678

Hume, M. (2010). Compassion without action: Examining the young consumers consumption and attitude to sustainable consumption. Journal of World Business, 45(4), 385-394. doi: 10.1016/j.jwb.2009.08.007

Husted, B. W. (1999). Wealth, culture, and corruption. Journal of International Business Studies, 30(2), 339-359. doi: 10.1057/palgrave.jibs. 8490073

Husted, B. W., \& Allen, D. B. (2009). Strategic corporate social responsibility and value creation. Management International Review, 49(6), 781-799. doi: 10.1007/s11575009-0016-5

Husted, B. W., Dozier, J. B., McMahon, J. T., \& Kattan, M. W. (1996). The impact of crossnational carriers of business ethics on attitudes about questionable practices and form of moral reasoning. Journal of International Business Studies, 27(2), 391-411. doi: 10.1057/palgrave.jibs.8490141

Husted, B. W., Montiel, I., \& Christmann, P. (2016). Effects of local legitimacy on certification decisions to global and national csr standards by multinational subsidiaries and domestic firms. Journal of International Business Studies, 47(3), 382397. doi: $10.1057 /$ jibs.2016.3

Ietto-Gillies, G. (2017). The organizational and geographical boundaries of the firm focus on labour as a major stakeholder. Critical Perspectives on International Business, 13(1), 72-92. doi: 10.1108/cpoib-11-2015-0050

Im, J., \& Sun, S. L. (2015). Profits and outreach to the poor: The institutional logics of microfinance institutions. Asia Pacific Journal of Management, 32(1), 95-117. doi: 10.1007/s10490-014-9398-4

Ioannou, I., \& Serafeim, G. (2012). What drives corporate social performance? The role of nation-level institutions. Journal of International Business Studies, 43(9), 834-864. doi: $10.1057 /$ jibs.2012.26

Ivanova, M. (2016). Shareholder activism and the ethical harnessing of institutional investors the unique case of shareaction. Critical Perspectives on International Business, 12(2), 189-214. doi: 10.1108/cpoib-09-2013-0032

Jaffe, E. D., \& Yi, L. (2007). What are the drivers of channel length? Distribution reform in the people's republic of china. International Business Review, 16(4), 474-493. doi: 10.1016/j.ibusrev.2007.04.001 
Jagannathan, S., Selvaraj, P., \& Joseph, J. (2016). The funeralesque as the experience of workers at the margins of international business seven indian narratives. Critical Perspectives on International Business, 12(3), 282-305. doi: 10.1108/cpoib-05-20150023

Jain, P. K., Kuvvet, E., \& Pagano, M. S. (2017). Corruption's impact on foreign portfolio investment. International Business Review, 26(1), 23-35. doi: 10.1016/j.ibusrev.2016.05.004

Jia, M., \& Zhang, Z. (2013). The ceo's representation of demands and the corporation's response to external pressures: Do politically affiliated firms donate more? Management and Organization Review, 9(1), 87-114. doi: 10.1111/j.17408784.2012.00297.x

Jimenez, A., Puche-Regaliza, J. C., Jimenez-Eguizabal, J. A., \& Alon, I. (2017). Political discretion and corruption: The impact of institutional quality on formal and informal entrepreneurship. European Journal of International Management, 11(3), 280-300. doi: 10.1504/ejim.2017.10004232

Jindra, B., Giroud, A., \& Scott-Kennel, J. (2009). Subsidiary roles, vertical linkages and economic development: Lessons from transition economies. Journal of World Business, 44(2), 167-179. doi: 10.1016/j.jwb.2008.05.006

Judge, W. Q., McNatt, D. B., \& Xu, W. C. (2011). The antecedents and effects of national corruption: A meta-analysis. Journal of World Business, 46(1), 93-103. doi: 10.1016/j.jwb.2010.05.021

Kandogan, Y. (2014). The effect of foreign trade and investment liberalization on spatial concentration of economic activity. International Business Review, 23(3), 648-659. doi: 10.1016/j.ibusrev.2013.11.005

Karam, C. M., Ralston, D. A., Egri, C. P., Butt, A., Srinivasan, N., Fu, P. P., . . Chia, H. B. (2013). Perceptions of the ethicality of favors at work in asia: An 11-society assessment. Asia Pacific Journal of Management, 30(2), 373-408. doi: 10.1007/s10490-012-9335-3

Kessler, S. R., Taylor, E. Z., Levine, E. L., Wiley, J. W., \& Kessler, L. M. (2008). Is a happy nation a productive nation? An exploration of the relationship between job satisfaction and productivity at the national level. European Journal of International Management, 2(3), 356-375. doi: 10.1504/ejim.2008.019701

Khattak, A., Haworth, N., Stringer, C., \& Benson-Rea, M. (2017). Is social upgrading occurring in south asia's apparel industry? Critical Perspectives on International Business, 13(3), 226-243. doi: 10.1108/cpoib-11-2015-0051

Kim, C. H., \& Scullion, H. (2011). Exploring the links between corporate social responsibility and global talent management: A comparative study of the uk and korea. European Journal of International Management, 5(5), 501-523.

Kolk, A. (2016). The social responsibility of international business: From ethics and the environment to csr and sustainable development. Journal of World Business, 51(1), 23-34. doi: 10.1016/j.jwb.2015.08.010

Kolk, A., \& Pinkse, J. (2008). A perspective on multinational enterprises and climate change: Learning from "an inconvenient truth"? Journal of International Business Studies, 39(8), 1359-1378. doi: 10.1057/jibs.2008.61

Kolk, A., \& Van Tulder, R. (2004). Ethics in international business: Multinational approaches to child labor. Journal of World Business, 39(1), 49-60. doi: 10.1016/j.jwb.2003.08.014

Kolk, A., \& van Tulder, R. (2010). International business, corporate social responsibility and sustainable development. International Business Review, 19(2), 119-125. doi: 10.1016/j.ibusrev.2009.12.003 
Kuruvilla, S., \& Zhang, H. (2016). Labor unrest and incipient collective bargaining in china. Management and Organization Review, 12(1), 159-187. doi: 10.1017/mor.2016.2

Kuznetsov, A., \& Kuznetsova, O. (2010). The role of stakeholders in shaping managerial perceptions of csr in russia. European Journal of International Management, 4(3), 257-272.

Labucay, I. (2015). Diversity management and performance: Paving the way for a revised business case. European Journal of International Management, 9(4), 425-441. doi: 10.1504/ejim.2015.070228

Lam, C. K., Walter, F., \& Ouyang, K. (2014). Display rule perceptions and job performance in a chinese retail firm: The moderating role of employees' affect at work. Asia Pacific Journal of Management, 31(2), 575-597. doi: 10.1007/s10490-013-9348-6

Langlois, C. C., \& Schlegelmilch, B. B. (1990). Do corporate codes of ethics reflect national character - evidence from europe and the united-states. Journal of International Business Studies, 21(4), 519-539. doi: 10.1057/palgrave.jibs.8490340

Lee, J., \& Gereffi, G. (2015). Global value chains, rising power firms and economic and social upgrading. Critical Perspectives on International Business, 11(3-4), 319-+. doi: 10.1108/cpoib-03-2014-0018

Lee, S. H., \& Hong, S. J. (2012). Corruption and subsidiary profitability: Us mnc subsidiaries in the asia pacific region. Asia Pacific Journal of Management, 29(4), 949-964. doi: 10.1007/s10490-010-9214-8

Lee, S. H., Oh, K., \& Eden, L. (2010). Why do firms bribe? Insights from residual control theory into firms' exposure and vulnerability to corruption. Management International Review, 50(6), 775-796. doi: 10.1007/s11575-010-0057-9

Lee, S. Y. (2016). Responsible supply chain management in the asian context: The effects on relationship commitment and supplier performance. Asia Pacific Business Review, 22(2), 325-342. doi: 10.1080/13602381.2015.1070012

Lehrer, M., Asakawa, K., \& Behnam, M. (2011). Home base-compensating r\&d: Indicators, public policy, and ramifications for multinational firms. Journal of International Management, 17(1), 42-53. doi: 10.1016/j.intman.2010.08.001

Lei, H. S., \& Chen, Y. S. (2011). The right tree for the right bird: Location choice decision of taiwanese firms' fdi in china and vietnam. International Business Review, 20(3), 338352. doi: 10.1016/j.ibusrev.2010.10.002

Leonidou, C. N., Leonidou, L. C., Coudounaris, D. N., \& Hultman, M. (2013). Value differences as determinants of importers' perceptions of exporters' unethical behavior: The impact on relationship quality and performance. International Business Review, 22(1), 156-173. doi: 10.1016/j.ibusrev.2012.03.005

Leonidou, L. C., Fotiadis, T. A., Christodoulides, P., Spyropoulou, S., \& Katsikeas, C. S. (2015). Environmentally friendly export business strategy: Its determinants and effects on competitive advantage and performance. International Business Review, 24(5), 798-811. doi: 10.1016/j.ibusrev.2015.02.001

Lepez-Vergara, M. P., \& Botero, I. C. (2015). The role of non-economic goals for psychological ownership in family firms. European Journal of International Management, 9(2), 201-220. doi: 10.1504/ejim.2015.067856

Leung, K., Zhu, Y. X., \& Ge, C. G. (2009). Compensation disparity between locals and expatriates: Moderating the effects of perceived injustice in foreign multinationals in china. Journal of World Business, 44(1), 85-93. doi: 10.1016/j.jwb.2008.03.010

Li, J., Young, M. N., \& Tang, G. Y. (2012). The development of entrepreneurship in chinese communities: An organizational symbiosis perspective. Asia Pacific Journal of Management, 29(2), 367-385. doi: 10.1007/s10490-010-9192-x 
Li, S. M., Fetscherin, M., Alon, I., Lattemann, C., \& Yeh, K. (2010). Corporate social responsibility in emerging markets the importance of the governance environment. Management International Review, 50(5), 635-654. doi: 10.1007/s11575-010-0049-9

Li, Y., Ashkanasy, N. M., \& Mehmood, K. (2017). The experience of anger and sadness in response to hurtful behavior: Effects of gender-pairing and national culture. Asia Pacific Journal of Management, 34(2), 423-441. doi: 10.1007/s10490-016-9493-9

Li, Y., Yao, F. K., \& Ahlstrom, D. (2015). The social dilemma of bribery in emerging economies: A dynamic model of emotion, social value, and institutional uncertainty. Asia Pacific Journal of Management, 32(2), 311-334. doi: 10.1007/s10490-014-94068

Lie, J. (2016). Political economy and business ethics. Asia Pacific Business Review, 22(3), 366-373. doi: 10.1080/13602381.2015.1129773

Lim, M. H., \& Lee, J. H. (2017). National economic disparity and cross-border acquisition resolution. International Business Review, 26(2), 354-364. doi: 10.1016/j.ibusrev.2016.09.004

Liu, T. Q., \& Stening, B. W. (2016). The contextualization and de-contextualization of confucian morality: Making confucianism relevant to china's contemporary challenges in business ethics. Asia Pacific Journal of Management, 33(3), 821-841. doi: 10.1007/s10490-015-9415-2

Liu, Y. H., Feng, T. L., \& Li, S. C. (2015). Stakeholder influences and organization responses: A case study of corporate social responsibility suspension. Management and Organization Review, 11(3), 469-491. doi: 10.1017/mor.2015.4

London, T., \& Hart, S. L. (2004). Reinventing strategies for emerging markets: Beyond the transnational model. Journal of International Business Studies, 35(5), 350-370. doi: 10.1057/palgrave.jibs.8400099

Lovett, S., Simmons, L. C., \& Kali, R. (1999). Guanxi versus the market: Ethics and efficiency. Journal of International Business Studies, 30(2), 231-247. doi: 10.1057/palgrave.jibs.8490068

Luo, J. H., Xiang, Y. G., \& Zhu, R. C. (2017). Military top executives and corporate philanthropy: Evidence from china. Asia Pacific Journal of Management, 34(3), 725755. doi: 10.1007/s10490-016-9499-3

Lynes, J. K., \& Andrachuk, M. (2008). Motivations for corporate social and environmental responsibility: A case study of scandinavian airlines. Journal of International Management, 14(4), 377-390. doi: 10.1016/j.intman.2007.09.004

Macklin, R., Martin, A., \& Mathison, K. (2015). An integrated model of justice and ethical climates and the influence of cultural diversity. Management and Organization Review, 11(1), 101-121. doi: 10.1111/more.12034

Magoshi, E., \& Chang, E. (2009). Diversity management and the effects on employees' organizational commitment: Evidence from japan and korea. Journal of World Business, 44(1), 31-40. doi: 10.1016/j.jwb.2008.03.018

Maignan, I., \& Ralston, D. A. (2002). Corporate social responsibility in europe and the us: Insights from businesses' self-presentations. Journal of International Business Studies, 33(3), 497-514. doi: 10.1057/palgrave.jibs.8491028

Maksimov, V., Wang, S. L., \& Luo, Y. D. (2017). Reducing poverty in the least developed countries: The role of small and medium enterprises. Journal of World Business, 52(2), 244-257. doi: 10.1016/j.jwb.2016.12.007

Mansur, J., Sobral, F., \& Goldszmidt, R. (2017). Shades of paternalistic leadership across cultures. Journal of World Business, 52(5), 702-713. doi: 10.1016/j.jwb.2017.06.003

Mao, Y. N., Wong, C. S., \& Peng, K. Z. (2013). Breaking institutionalized corruption: Is the experience of the hong kong independent commission against corruption generalizable? 
Asia Pacific Journal of Management, 30(4), 1115-1124. doi: 10.1007/s10490-0139351-y

Marano, V., \& Tashman, P. (2012). Mne/ngo partnerships and the legitimacy of the firm. International Business Review, 21(6), 1122-1130. doi: 10.1016/j.ibusrev.2011.12.005

Marano, V., Tashman, P., \& Kostova, T. (2017). Escaping the iron cage: Liabilities of origin and csr reporting of emerging market multinational enterprises. Journal of International Business Studies, 48(3), 386-408. doi: 10.1057/jibs.2016.17

Marquis, C., Yin, J. L., \& Yang, D. N. (2017). State-mediated globalization processes and the adoption of corporate social responsibility reporting in china. Management and Organization Review, 13(1), 167-191. doi: 10.1017/mor.2016.55

Maruyama, M., \& Wu, L. H. (2015). Overcoming the liability of foreignness in international retailing: A consumer perspective. Journal of International Management, 21(3), 200210. doi: 10.1016/j.intman.2015.07.001

McPhail, R., \& McNulty, Y. (2015). 'Oh, the places you won't go as an lgbt expat!' A study of hrm's duty of care to lesbian, gay, bisexual and transgender expatriates in dangerous locations. European Journal of International Management, 9(6), 737-765. doi: 10.1504/ejim.2015.072227

Mendez-Picazo, M. T., Ribeiro-Soriano, D., \& Galindo-Martin, M. A. (2015). Drivers of social entrepreneurship. European Journal of International Management, 9(6), 766779. doi: 10.1504/ejim.2015.072214

Meng, X. H., Zeng, S. X., Xie, X. M., \& Qi, G. Y. (2016). The impact of product market competition on corporate environmental responsibility. Asia Pacific Journal of Management, 33(1), 267-291. doi: 10.1007/s10490-015-9450-z

Mersland, R., Randoy, T., \& Strom, R. O. (2011). The impact of international influence on microbanks' performance: A global survey. International Business Review, 20(2), 163 176. doi: 10.1016/j.ibusrev.2010.07.006

Meyer, K. E., \& Thein, H. H. (2014). Business under adverse home country institutions: The case of international sanctions against myanmar. Journal of World Business, 49(1), 156-171. doi: 10.1016/j.jwb.2013.04.005

Michie, J., \& Rowley, C. (2014). Mutuality in the asia pacific region. Asia Pacific Business Review, 20(3), 506-511. doi: 10.1080/13602381.2014.937922

Mirowska, A. (2008). How to get employees to work with you, not just for you: An action model and propositions. European Journal of International Management, 2(3), 269286. doi: 10.1504/ejim.2008.019697

Miska, C., Stahl, G. K., \& Mendenhall, M. E. (2013). Intercultural competencies as antecedents of responsible global leadership. European Journal of International Management, 7(5), 550-569. doi: 10.1504/ejim.2013.056477

Morgenroth, A., \& Luiz, J. M. (2017). Corporate social responsibility mandates within german multinational enterprises in sub-saharan africa. European Journal of International Management, 10(6), 624-646. doi: 10.1504/ejim.2016.10000339

Mudambi, R., Navarra, P., \& Delios, A. (2013). Government regulation, corruption, and fdi. Asia Pacific Journal of Management, 30(2), 487-511. doi: 10.1007/s10490-012-9311$\mathrm{y}$

Mueller, J., Abfalter, D., Hautz, J., Hutter, K., Matzler, K., \& Raich, M. (2011). Differences in corporate environmentalism - a comparative analysis of leading us and german companies. European Journal of International Management, 5(2), 122-148. doi: 10.1504/ejim.2011.038814

Muethel, M., Hoegl, M., \& Parboteeah, K. P. (2011). National business ideology and employees' prosocial values. Journal of International Business Studies, 42(2), 183-201. doi: 10.1057/jibs.2010.47 
Munoz, R. M., de Pablo, J. D. S., \& Pena, I. (2015). Linking corporate social responsibility and financial performance in spanish firms. European Journal of International Management, 9(3), 368-383. doi: 10.1504/ejim.2015.069133

Myers, M. B. (1999). Incidents of gray market activity among us exporters: Occurrences, characteristics, and consequences. Journal of International Business Studies, 30(1), 105-126. doi: 10.1057/palgrave.jibs. 8490062

Newburry, W., Gardberg, N. A., \& Sanchez, J. I. (2014). Employer attractiveness in latin america: The association among foreignness, internationalization and talent recruitment. Journal of International Management, 20(3), 327-344. doi: 10.1016/j.intman.2014.01.001

Ngobo, P. V., \& Fouda, M. (2012). Is 'good' governance good for business? A cross-national analysis of firms in african countries. Journal of World Business, 47(3), 435-449. doi: 10.1016/j.jwb.2011.05.010

Oetzel, J., \& Getz, K. (2012). Why and how might firms respond strategically to violent conflict? Journal of International Business Studies, 43(2), 166-186. doi: 10.1057/jibs.2011.50

Olckers, C., \& Du Plessis, Y. (2015). Psychological ownership as a requisite for talent retention: The voice of highly skilled employees. European Journal of International Management, 9(1), 52-73. doi: 10.1504/ejim.2015.066671

Omoteso, K., \& Yusuf, H. (2017). Accountability of transnational corporations in the developing world the case for an enforceable international mechanism. Critical Perspectives on International Business, 13(1), 54-71. doi: 10.1108/cpoib-08-20140040

Osabutey, E. L. C., \& Okoro, C. (2015). Political risk and foreign direct investment in africa: The case of the nigerian telecommunications industry. Thunderbird International Business Review, 57(6), 417-429. doi: 10.1002/tie.21672

Park, B. I., Chidlow, A., \& Choi, J. (2014). Corporate social responsibility: Stakeholders influence on mnes' activities. International Business Review, 23(5), 966-980. doi: 10.1016/j.ibusrev.2014.02.008

Park, B. I., \& Ghauri, P. N. (2015). Determinants influencing csr practices in small and medium sized mne subsidiaries: A stakeholder perspective. Journal of World Business, 50(1), 192-204. doi: 10.1016/j.jwb.2014.04.007

Patterson, L., \& Walcutt, B. (2013). Korean workplace gender discrimination research analysis: A review of the literature from 1990 to 2010. Asia Pacific Business Review, 19(1), 85-101. doi: 10.1080/13602381.2012.697774

Patterson, L., \& Walcutt, B. (2014). Explanations for continued gender discrimination in south korean workplaces. Asia Pacific Business Review, 20(1), 18-41. doi: 10.1080/13602381.2013.818805

Peredo, A. M., \& McLean, M. (2006). Social entrepreneurship: A critical review of the concept. Journal of World Business, 41(1), 56-65. doi: 10.1016/j.jwb.2005.10.007

Petrovskaya, I., Zaverskiy, S., \& Kiseleva, E. (2016). Putting assumptions into words: Money and work beliefs and legitimacy of entrepreneurship in russia. European Journal of International Management, 10(2), 157-180. doi: 10.1504/ejim.2016.074470

Pinkse, J., \& Kolk, A. (2012). Multinational enterprises and climate change: Exploring institutional failures and embeddedness. Journal of International Business Studies, 43(3), 332-341. doi: 10.1057/jibs.2011.56

Polo, F. C., \& Vazquez, D. (2008). Social information within the intellectual capital report. Journal of International Management, 14(4), 353-363. doi: 10.1016/j.intman.2007.09.007 
Purdy, J. M., Alexander, E. A., \& Neill, S. (2010). The impact of national institutional context on social practices: Comparing finnish and us business communities. European Journal of International Management, 4(3), 234-256.

Ralston, D. A., Egri, C. P., Carranza, M. T. D., Ramburuth, P., Terpstra-Tong, J., Pekerti, A. A., ... Wallace, A. (2009a). Ethical preferences for influencing superiors: A 41society study. Journal of International Business Studies, 40(6), 1022-1045. doi: $10.1057 /$ jibs. 2008.109

Ralston, D. A., Egri, C. P., Casado, T., Fu, P. P., \& Wangenheim, F. (2009b). The impact of life stage and societal culture on subordinate influence ethics: A study of brazil, china, germany, and the us. Journal of International Management, 15(4), 374-386. doi: 10.1016/j.intman.2009.02.004

Ralston, D. A., Egri, C. P., Karam, C. M., Naoumova, I., Srinivasan, N., Casado, T., . . Alas, R. (2015). The triple-bottom-line of corporate responsibility: Assessing the attitudes of present and future business professionals across the brics. Asia Pacific Journal of Management, 32(1), 145-179. doi: 10.1007/s10490-014-9376-x

Ramirez, J., Velez-Zapata, C., \& Madero, S. (2015). Building psychological contracts in security-risk environments: Evidence from colombia and mexico. European Journal of International Management, 9(6), 690-711. doi: 10.1504/ejim.2015.072225

Rao, A. (2012). Managing diversity: Impact of religion in the indian workplace. Journal of World Business, 47(2), 232-239. doi: 10.1016/j.jwb.2011.04.010

Rathert, N. (2016). Strategies of legitimation: Mnes and the adoption of csr in response to host-country institutions. Journal of International Business Studies, 47(7), 858-879. doi: $10.1057 /$ jibs.2016.19

Redfern, K., \& Crawford, J. (2010). Regional differences in business ethics in the people's republic of china: A multi-dimensional approach to the effects of modernisation. Asia Pacific Journal of Management, 27(2), 215-235. doi: 10.1007/s10490-008-9097-0

Reis, Y., \& Guedes, A. L. (2017). International environmental ngos and the politics of genetically modified organisms rethinking resistance in international business. Critical Perspectives on International Business, 13(1), 23-37. doi: 10.1108/cpoib-03-20140020

Ren, X. N., \& Foster, D. (2011). Women's experiences of work and family conflict in a chinese airline. Asia Pacific Business Review, 17(3), 325-341. doi: 10.1080/13602380903462159

Riaz, Z., Ray, S., Ray, P. K., \& Kumar, V. (2015). Disclosure practices of foreign and domestic firms in australia. Journal of World Business, 50(4), 781-792. doi: 10.1016/j.jwb.2015.04.001

Robertson, C. J., Gilley, K. M., \& Street, M. D. (2003). The relationship between ethics and firm practices in russia and the united states. Journal of World Business, 38(4), 375384. doi: 10.1016/j.jwb.2003.08.022

Rodgers, W. (2009). Auditor independence and corporate governance: Ethical dilemmas. European Journal of International Management, 3(1), 60-74.

Rowley, C., \& Andrews, T. G. (2017). Special issue of asia pacific business review: Business and management corruption in the asia pacific: Corrupting and corruptors in and around organizations. Asia Pacific Business Review, 23(4), 621-624. doi: 10.1080/13602381.2017.1346920

Rowley, C., \& Michie, J. (2014). Differing forms of capital: Setting the scene for mutuality and co-operation in the asia pacific region. Asia Pacific Business Review, 20(3), 322329. doi: 10.1080/13602381.2014.937912 
Rowley, C., \& Oh, I. (2016a). Business ethics and the role of context: Institutionalism, history and comparisons in the asia pacific region. Asia Pacific Business Review, 22(3), 353365. doi: 10.1080/13602381.2015.1129814

Rowley, C., \& Oh, I. (2016b). Relinquishing business ethics from a theoretical deadlock: The requirement for local grounding and historical comparisons in the asia pacific region. Asia Pacific Business Review, 22(3), 516-521. doi: 10.1080/13602381.2015.1129813

Rugman, A. M., \& Kirton, J. (1998). Multinational enterprise strategy and the nafta trade and environment regime. Journal of World Business, 33(4), 438-454. doi: 10.1016/s10909516(98)90026-8

Santangelo, G. D. (2009). Mncs and linkages creation: Evidence from a peripheral area. Journal of World Business, 44(2), 192-205. doi: 10.1016/j.jwb.2008.05.009

Sanyal, R. N. (1990). An empirical-analysis of the unionization of foreign manufacturing firms in the united-states. Journal of International Business Studies, 21(1), 119-132. doi: 10.1057/palgrave.jibs.8490330

Sanyal, R. N., \& Neves, J. S. (1992). A study of union ability to secure the 1st contract in foreign-owned firms in the USA. Journal of International Business Studies, 23(4), 697-713. doi: 10.1057/palgrave.jibs. 8490284

Sarkar, S. (2009). Individualism-collectivism as predictors of bpo employee attitudes toward union membership in india. Asia Pacific Journal of Management, 26(1), 93-118. doi: 10.1007/s10490-007-9080-1

Schlegelmilch, B. B., \& Robertson, D. C. (1995). The influence of country and industry on ethical perceptions of senior executives in the us and europe. Journal of International Business Studies, 26(4), 859-881. doi: 10.1057/palgrave.jibs.8490823

Selmier, W. T., Newenham-Kahindi, A., \& Oh, C. H. (2015). "Understanding the words of relationships": Language as an essential tool to manage csr in communities of place. Journal of International Business Studies, 46(2), 153-179. doi: 10.1057/jibs.2014.58

Serrano-Cinca, C., \& Gutierrez-Nieto, B. (2014). Microfinance, the long tail and mission drift. International Business Review, 23(1), 181-194. doi: 10.1016/j.ibusrev.2013.03.006

Shao, L. A., Kwok, C. C. Y., \& Guedhami, O. (2010). National culture and dividend policy. Journal of International Business Studies, 41(8), 1391-1414. doi: $10.1057 /$ jibs.2009.74

Sharir, M., \& Lerner, M. (2006). Gauging the success of social ventures initiated by individual social entrepreneurs. Journal of World Business, 41(1), 6-20. doi: 10.1016/j.jwb.2005.09.004

Shaver, J. M. (1998). Do foreign-owned and us-owned establishments exhibit the same location pattern in us manufacturing industries? Journal of International Business Studies, 29(3), 469-492.

Shinkle, G. A., \& Spencer, J. W. (2012). The social construction of global corporate citizenship: Sustainability reports of automotive corporations. Journal of World Business, 47(1), 123-133. doi: 10.1016/j.jwb.2011.02.003

Shirodkar, V., \& Mohr, A. T. (2015). Explaining foreign firms' approaches to corporate political activity in emerging economies: The effects of resource criticality, product diversification, inter-subsidiary integration, and business ties. International Business Review, 24(4), 567-579. doi: 10.1016/j.ibusrev.2014.10.014

Si, S., Yu, X. B., Wu, A. Q., Chen, S. M., Chen, S., \& Su, Y. Y. (2015). Entrepreneurship and poverty reduction: A case study of yiwu, china. Asia Pacific Journal of Management, 32(1), 119-143. doi: 10.1007/s10490-014-9395-7

Singh, J., Carasco, E., Svensson, G., Wood, G., \& Callaghan, M. (2005). A comparative study of the contents of corporate codes of ethics in australia, canada and sweden. Journal of World Business, 40(1), 91-109. doi: 10.1016/j.jwb.2004.10.007 
Sinkovics, N., Hoque, S. F., \& Sinkovics, R. R. (2016). Rana plaza collapse aftermath: Are csr compliance and auditing pressures effective? Accounting, Auditing \& Accountability Journal, 29(4), 617-649. doi: doi:10.1108/AAAJ-07-2015-2141

Sinkovics, N., Sinkovics, R. R., Hoque, S. F., \& Czaban, L. (2015). A reconceptualisation of social value creation as social constraint alleviation. Critical Perspectives on International Business, 11(3/4), 340-363. doi: doi:10.1108/cpoib-06-2014-0036

Sinkovics, N., Sinkovics, R. R., \& Mo, Y. M. (2014). The role of social value creation in business model formulation at the bottom of the pyramid - implications for mnes? International Business Review, 23(4), 692-707. doi: 10.1016/j.ibusrev.2013.12.004

Soltani, E., Syed, J., Liao, Y. Y., \& Shahi-Sough, N. (2012). Tackling one-sidedness in equality and diversity research: Characteristics of the current dominant approach to managing diverse workgroups in iran. Asia Pacific Journal of Management, 29(1), 937. doi: 10.1007/s10490-011-9259-3

Song, Y. Y., Gianiodis, P. T., \& Li, Y. X. (2016). Institutional ownership and corporate philanthropic giving in an emerging economy. Management and Organization Review, 12(2), 357-385. doi: 10.1017/mor.2015.33

Spais, G. S., \& Beheshti, H. M. (2016). The evolution of social marketing and social entrepreneurship education in business and management schools: Conceptions, misconceptions and trends. European Journal of International Management, 10(4), 422-454. doi: 10.1504/ejim.2016.077423

Spais, G. S., \& Kaufmann, H. R. (2016). Are there "honorable merchants" in international marketing channels? Thunderbird International Business Review, 58(3), 199-211. doi: $10.1002 /$ tie. 21728

Srikantia, J. (2016). The structural violence of globalization. Critical Perspectives on International Business, 12(3), 222-258. doi: 10.1108/cpoib-09-2015-0040

Stajkovic, A. D., \& Luthans, A. D. (1997). Business ethics across cultures: A social cognitive model. Journal of World Business, 32(1), 17-34. doi: 10.1016/s1090-9516(97)90023-7

Stephan, U., Uhlaner, L. M., \& Stride, C. (2015). Institutions and social entrepreneurship: The role of institutional voids, institutional support, and institutional configurations. Journal of International Business Studies, 46(3), 308-331. doi: 10.1057/jibs.2014.38

Strike, V. M., Gao, J. J., \& Bansal, P. (2006). Being good while being bad: Social responsibility and the international diversification of us firms. Journal of International Business Studies, 37(6), 850-862. doi: 10.1057/palgrave.jibs.8400226

Suder, G., Liesch, P. W., Inomata, S., Mihailova, I., \& Meng, B. (2015). The evolving geography of production hubs and regional value chains across east asia: Trade in value-added. Journal of World Business, 50(3), 404-416. doi: 10.1016/j.jwb.2014.05.003

Sui, S., Morgan, H. M., \& Baum, M. (2015). Internationalization of immigrant-owned smes: The role of language. Journal of World Business, 50(4), 804-814. doi: 10.1016/j.jwb.2015.04.002

Sunduramurthy, C., Zheng, C. C., Musteen, M., Francis, J., \& Rhyne, L. (2016). Doing more with less, systematically? Bricolage and ingenieuring in successful social ventures. Journal of World Business, 51(5), 855-870. doi: 10.1016/j.jwb.2016.06.005

Swoboda, B., Huber, C., Schuster, T., \& Hirschmann, J. (2017). Corporate reputation effects across nations: The impact of country distances and firm-specific resources. Management International Review, 57(5), 717-748. doi: 10.1007/s11575-017-0313-3

Syed, J. (2008). A context-specific perspective of equal employment opportunity in islamic societies. Asia Pacific Journal of Management, 25(1), 135-151. doi: 10.1007/s10490007-9051-6 
Tatli, A., Vassilopoulou, J., \& Ozbilgin, M. (2013). An unrequited affinity between talent shortages and untapped female potential: The relevance of gender quotas for talent management in high growth potential economies of the asia pacific region. International Business Review, 22(3), 539-553. doi: 10.1016/j.ibusrev.2012.07.005

Tatoglu, E., Bayraktar, E., Sahadev, S., Demirbag, M., \& Glaister, K. W. (2014). Determinants of voluntary environmental management practices by mne subsidiaries. Journal of World Business, 49(4), 536-548. doi: 10.1016/j.jwb.2013.12.007

Terjesen, S., \& Hessels, J. (2009). Varieties of export-oriented entrepreneurship in asia. Asia Pacific Journal of Management, 26(3), 537-561. doi: 10.1007/s10490-009-9138-3

Tillmann, W., Pelin, B., \& R., H. Z. (2008). The dark side of retailing: Towards a scale of corporate social irresponsibility. International Journal of Retail \& Distribution Management, 36(2), 124-142. doi: doi:10.1108/09590550810853075

Tüselmann, H., Sinkovics, R. R., \& Pishchulov, G. (2016). Revisiting the standing of international business journals in the competitive landscape. Journal of World Business, 51(4), 487-498. doi: https://doi.org/10.1016/j.jwb.2016.01.006

Tymon, W. G., Stumpf, S. A., \& Doh, J. P. (2010). Exploring talent management in india: The neglected role of intrinsic rewards. Journal of World Business, 45(2), 109-121. doi: 10.1016/j.jwb.2009.09.016

Uldam, J., \& Hansen, H. K. (2017). Corporate responses to stakeholder activism: Partnerships and surveillance. Critical Perspectives on International Business, 13(2), 151-165. doi: 10.1108/cpoib-07-2015-0029

Vachani, S., Doh, J. P., \& Teegen, H. (2009). Ngos' influence on mnes' social development strategies in varying institutional contexts: A transaction cost perspective. International Business Review, 18(5), 446-456. doi: 10.1016/j.ibusrev.2009.05.002

Van Eck, N. J., \& Waltman, L. (2014). Visualizing bibliometric networks In Y. Ding, R. Rousseau \& D. Wolfram (Eds.), Measuring scholarly impact: Methods and practice (pp. 285-320): Springer

Veenendaal, A. A. R., van Velzen, M., \& Looise, J. K. (2014). Affecting innovation through hrm: The role of creative capital. European Journal of International Management, 8(5), 472-487. doi: 10.1504/ejim.2014.064600

von Staden, P. (2016). A sociocognitive approach to business ethics: Lessons from early industrializing japan. Asia Pacific Business Review, 22(3), 411-421. doi: 10.1080/13602381.2015.1129775

Wagner, M. (2015). A european perspective on country moderation effects: Environmental management systems and sustainability-related human resource benefits. Journal of World Business, 50(2), 379-388. doi: 10.1016/j.jwb.2014.08.005

Wan, H. L., Sulaiman, M., \& Omar, A. (2012). Procedural justice in promotion decisions of managerial staff in malaysia. Asia Pacific Business Review, 18(1), 99-121. doi: $10.1080 / 13602380903424167$

Wang, A. C., Chiang, J. T. J., Chou, W. J., \& Cheng, B. S. (2017). One definition, different manifestations: Investigating ethical leadership in the chinese context. Asia Pacific Journal of Management, 34(3), 505-535. doi: 10.1007/s10490-016-9495-7

Wang, A. C., Hsieh, H. H., Tsai, C. Y., \& Cheng, B. S. (2012). Does value congruence lead to voice? Cooperative voice and cooperative silence under team and differentiated transformational leadership. Management and Organization Review, 8(2), 341-370. doi: 10.1111/j.1740-8784.2011.00255.x

Wang, L. H., Cui, Z. Y., \& Liang, X. Y. (2015). Does it pay to be green? Financial benefits of environmental labeling among chinese firms, 2000-2005. Management and Organization Review, 11(3), 493-519. doi: 10.1017/mor.2014.8 
Wang, Y., \& Sun, S. J. (2010). Assessing beliefs, attitudes, and behavioral responses toward online advertising in three countries. International Business Review, 19(4), 333-344. doi: 10.1016/j.ibusrev.2010.01.004

Wei, H. G., Zhu, Y. X., \& Li, S. B. (2016). Top executive leaders' compassionate actions: An integrative framework of compassion incorporating a confucian perspective. Asia Pacific Journal of Management, 33(3), 767-787. doi: 10.1007/s 10490-016-9463-2

Weitzel, U., \& Berns, S. (2006). Cross-border takeovers, corruption, and related aspects of governance. Journal of International Business Studies, 37(6), 786-806. doi: 10.1057 /palgrave.jibs. 8400225

Wettstein, F. (2012). Csr and the debate on business and human rights: Bridging the great divide. Business Ethics Quarterly, 22(4), 739-770. doi: 10.5840/beq201222446

Whitman, M. E., Townsend, A. M., \& Hendrickson, A. R. (1999). Cross-national differences in computer-use ethics: A nine-country study. Journal of International Business Studies, 30(4), 673-687. doi: 10.1057/palgrave.jibs.8490833

Windsor, D. (2009). Tightening corporate governance. Journal of International Management, 15(3), 306-316. doi: 10.1016/j.intman.2009.02.003

Wood, T., \& da Costa, A. P. P. (2015). Corporate frauds as criminal business models: An exploratory study. Thunderbird International Business Review, 57(1), 51-62. doi: 10.1002/tie. 21676

Wu, W., Tang, F. C., Dong, X. Y., \& Liu, C. L. (2015). Different identifications cause different types of voice: A role identity approach to the relations between organizational socialization and voice. Asia Pacific Journal of Management, 32(1), 251-287. doi: 10.1007/s 10490-014-9384-X

Xing, Y. J., Liu, Y. P., Tarba, S. Y., \& Cooper, C. L. (2016). Intercultural influences on managing african employees of chinese firms in africa: Chinese managers' hrm practices. International Business Review, 25(1), 28-41. doi: 10.1016/j.ibusrev.2014.05.003

Xu, E. M., Yang, H., Quan, J. M., \& Lu, Y. (2015). Organizational slack and corporate social performance: Empirical evidence from china's public firms. Asia Pacific Journal of Management, 32(1), 181-198. doi: 10.1007/s10490-014-9401-0

Yang, Q., \& Liu, M. X. (2014). Ethical leadership, organizational identification and employee voice: Examining moderated mediation process in the chinese insurance industry. Asia Pacific Business Review, 20(2), 231-248. doi: 10.1080/13602381.2013.823712

Yolles, M. (2007). Modelling pathologies in social collectives. European Journal of International Management, 1(1-2), 81-103. doi: 10.1504/ejim.2007.012919

Young, S. L., \& Makhija, M. V. (2014). Firms' corporate social responsibility behavior: An integration of institutional and profit maximization approaches. Journal of International Business Studies, 45(6), 670-698. doi: 10.1057/jibs.2014.29

Yuan, L., Pangarkar, N., \& Wu, J. (2016). The interactive effect of time and host country location on chinese mncs' performance: An empirical investigation. Journal of World Business, 51(2), 331-342. doi: 10.1016/j.jwb.2015.11.006

Zanakis, S. H., Newburry, W., \& Taras, V. (2016). Global social tolerance index and multimethod country rankings sensitivity. Journal of International Business Studies, 47(4), 480-497. doi: 10.1057/jibs.2016.5

Zeng, F., Li, J., Zhu, H., Cai, Z. Y., \& Li, P. C. (2013). How international firms conduct societal marketing in emerging markets. Management International Review, 53(6), 841-868. doi: 10.1007/s11575-013-0179-y

Zhang, Z. X., Wei, X., Chao, M. M., \& Zheng, Y. (2017). When do conflicts feel right for prevention-focused individuals? The debiasing effect of low need for closure. Management and Organization Review, 13(2), 375-397. doi: 10.1017/mor.2017.7 
Zhao, M., Park, S. H., \& Zhou, N. (2014). Mnc strategy and social adaptation in emerging markets. Journal of International Business Studies, 45(7), 842-861. doi: 10.1057/jibs.2014.8

Zheng, Q. Q., Luo, Y. D., \& Maksimov, V. (2015). Achieving legitimacy through corporate social responsibility: The case of emerging economy firms. Journal of World Business, 50(3), 389-403. doi: 10.1016/j.jwb.2014.05.001

Zheng, X. L., El Ghoul, S., Guedhami, O., \& Kwok, C. C. Y. (2013). Collectivism and corruption in bank lending. Journal of International Business Studies, 44(4), 363-390. doi: $10.1057 /$ jibs.2013.19

Zhou, J. Q., \& Peng, M. W. (2012). Does bribery help or hurt firm growth around the world? Asia Pacific Journal of Management, 29(4), 907-921. doi: 10.1007/s10490-011-92744

Zhu, Y., Sun, L. Y., \& Leung, A. S. M. (2014). Corporate social responsibility, firm reputation, and firm performance: The role of ethical leadership. Asia Pacific Journal of Management, 31(4), 925-947. doi: 10.1007/s10490-013-9369-1 


\section{Appendix}

\subsection{Appendix 1: Search terms}

corporate social responsibility, CSR, responsible business, responsible behavior, responsibility, social responsibility, social performance, society interface, triple bottom line, environmental sustainability, environmentally sustainable, green innovation, green supply chain, green management, social value, social entrepreneurship, social upgrading, social entrepreneur, social business, corporate social entrepreneurship, economic development, bottom of the pyramid, base of the pyramid, BOP, economically marginalized, developmental impact, corporate citizenship, NGO, non-governmental organization, private standard, private regulation, civil society, civil society organization, CSR standard, labor standard, sustainability standard, CSI, CSIR, corporate social irresponsibility, corporate irresponsibility, irresponsible, irresponsible business, irresponsible behavior, business ethics, unethical, ethical, ethics, natural environment, local businesses, working condition, discrimination, labor, overtime, living wage, health and safety, captive, sales practices, worker voice, worker rights, employee voice, unionization, worker union, labor relations, offensive material, pricing policies, pollution, climate change, discrimination, extreme weather, poor, poverty, corruption, tax avoidance, dishonesty, false advertisement, offensive material, working condition, abuse, human rights, forced labor, modern slavery, slavery, bonded labor, downgrading, child labor, insecurity, fraud, bribe, greed, unfairness, social justice, injustice, crime, greenwashing, whitewashing, social exclusion, organizational misbehavior, philanthropy, humiliation, and gender inequality 


\subsection{Tables and Figures}

Table 3.1 The distribution of publications across journals and clusters

\begin{tabular}{|c|c|c|c|c|c|c|c|c|c|c|c|}
\hline Journals & $\begin{array}{l}\text { 1. Ethics, management, } \\
\text { and contextual factors }\end{array}$ & $\begin{array}{c}2 . \\
\text { Antecedents } \\
\text { and outcomes } \\
\text { of CSR }\end{array}$ & $\begin{array}{c}\text { 3. FDI and } \\
\text { economic } \\
\text { development }\end{array}$ & $\begin{array}{l}\text { 4. Institutional } \\
\text { dynamics and } \\
\text { non-market } \\
\text { strategies }\end{array}$ & $\begin{array}{c}\text { 5. Business models } \\
\text { and } \\
\text { entrepreneurship } \\
\text { in developing } \\
\text { markets }\end{array}$ & 6. Corruption & $\begin{array}{c}\text { 7. Non- } \\
\text { market } \\
\text { strategies - } \\
\text { drivers, } \\
\text { implementati } \\
\text { on, and } \\
\text { outcomes }\end{array}$ & $\begin{array}{c}8 . \\
\text { Novel } \\
\text { topics } \\
\text { in IB }\end{array}$ & Other & $\begin{array}{l}\text { Total } \\
\text { responsibility- } \\
\text { related }\end{array}$ & $\begin{array}{l}\text { Total } \\
\text { publish } \\
\text { ed in } \\
\text { journal } \\
2\end{array}$ \\
\hline APBR & 9 & 4 & 2 & 13 & 7 & 1 & 2 & & 2 & 40 & 285 \\
\hline APJM & 17 & 7 & 2 & 6 & 8 & 7 & 1 & & & 48 & 371 \\
\hline CPOIB & & 4 & 2 & 1 & 2 & & & 8 & & 17 & 55 \\
\hline EJIM & 19 & 13 & 3 & 5 & 5 & 1 & 1 & 2 & & 49 & 338 \\
\hline GSJ & 1 & 1 & & 2 & 1 & & 2 & & & 7 & 119 \\
\hline IBR & 9 & 15 & 16 & 8 & 10 & 5 & 5 & 2 & & 70 & 814 \\
\hline JEWB & 1 & & & & & 1 & & & & 2 & 43 \\
\hline JIBS & 19 & 12 & 6 & 5 & 6 & 8 & 11 & 2 & 2 & 71 & 1542 \\
\hline JIM & 3 & 5 & 7 & 2 & 3 & 4 & 1 & & & 25 & 276 \\
\hline JWB & 18 & 16 & 13 & 6 & 12 & 7 & 7 & 5 & 1 & 85 & 795 \\
\hline MOR & 5 & 2 & & 7 & 2 & 2 & 3 & 1 & 1 & 23 & 213 \\
\hline MIR & 3 & 5 & 7 & 2 & 1 & 2 & 2 & & 6 & 28 & 1070 \\
\hline MBR & & & 2 & 1 & & & 2 & & & 5 & 58 \\
\hline TIR & 1 & 3 & 5 & 3 & 2 & & & & & 14 & 113 \\
\hline Grand Total & 105 & 87 & 65 & 61 & 59 & 38 & 37 & 20 & 12 & 484 & 6092 \\
\hline
\end{tabular}

${ }^{2}$ The cut-off point for the data collection was October 2017 


\begin{tabular}{|c|c|}
\hline luster 1: Ethics, management, and contextual factors & Cluster 2: Corporate social responsibility \\
\hline $\begin{array}{l}\text { - Leadership: Contextual antecedents and leadership, Conditions fostering firm-level ethics } \\
\text { - } \quad \text { HRM: Employee retention, Representation, Equality, diversity \& fairness, Working conditions } \\
\text { - } \quad \text { Marketing ethics: Online advertising, Impact of nationality on ethics of sales, Social marketing } \\
\text { advertising, Unethical marketing } \\
\text { - Entrepreneurial morality: Determinants of entrepreneurial morality } \\
\text { - Theoretical integration efforts: Business ethics and neoclassical theory, Evolution of } \\
\text { institutional ethics }\end{array}$ & $\begin{array}{l}\text { - Antecedents and outcomes of CSR: Firm level, Institutional level, Stakeholder } \\
\text { pressures, Business case for CSR (organizational benefits) } \\
\text { - } \quad \text { arporate political activity: Corporate diplomacy, Overt and covert political } \\
\text { - Attitity, Political activity intensity } \\
\text { students } \\
\text { - CSR and brand-related issues: Brand differentiation, Brand reputation } \\
\text { - Environmental responsibility (ER): Factors influencing ER, Firm-level outcomes } \\
\text { - Governance: Antecedents and outcomes of disclosure, Cross-cultural research } \\
\text { Sustainability: Brand commitment, HR involvement, Lean production in supply } \\
\text { chains, Sustainability in emerging economies, Impact of culture and regulations, } \\
\text { Sustainability accounting, Sustainable value creation }\end{array}$ \\
\hline Cluster 3: FDI and ec & Cluster 4: Institutional dynamics and non-market strategies \\
\hline $\begin{array}{ll}\text { - } & \text { Explicit } \\
\text { - Implicit: Economic development as a moderating variable, Economic development as a control } \\
\text { variable, Economic development as context }\end{array}$ & $\begin{array}{l}\text { - Impact of institutional dynamics: Legitimacy, Corporate culture, Institutional } \\
\text { constraints, Market financing, Innovation, Diversity, MNE transaction costs, Risk } \\
\text { management, Political ties (Political activity/Political connectedness) } \\
\text { - Corporate governance: Family control, Governance in weak institutional settings, } \\
\text { Owner structure influence, Institutional convergence, Informal institutions, } \\
\text { Tightening corporate governance, Risk management } \\
\text { - Institutional voids (IV): CSR as a response to IV, No business group influence } \\
\text { - Philanthropic behavior: Factors influencing philanthropic behavior (Mitigate } \\
\text { environmental outcomes / impact upon firm performance / Foreign giving as a } \\
\text { strategic resource), Outcomes (Mitigate environmental outcomes / impact upon } \\
\text { firm performance / Foreign giving as a strategic resource) }\end{array}$ \\
\hline Cluster 5: Busines & uster 6: Corruption \\
\hline $\begin{array}{l}\text { - Business' development role: Employment, Crime in EM, Cross-sector partnership, } \\
\text { Environment-based issues, Entrepreneurship, CSR-based issues, Micro-finance, Social } \\
\text { embeddedness, Markets for the poor } \\
\text { - Social entrepreneurship: Factors affecting success, Conceptual developments, Social enterprise } \\
\text { capabilities, Other (e.g. hybrid models in SSA) }\end{array}$ & $\begin{array}{l}\text { Conceptualization \& operationalization: Critical assessment of corruption, } \\
\text { Historical roots of corruption, Negative consequence of corruption, Special Asian } \\
\text { case, Summary of corruption literature } \\
\text { - Country-level investigations: Antecedents and effects of corruption, Role of } \\
\text { institutions in tackling corruption, Other (e.g. occurrence in cronyism) } \\
\text { - Firm-level investigations: Bribery behavior in firms, Firm-level outcome of } \\
\text { corruption, MNEs as agents of change, Other (e.g. trading favors) }\end{array}$ \\
\hline Cluster 7: Implementation of non-market strategies & Cluster 8: Under-represented topics in IB \\
\hline $\begin{array}{l}\text { - Conceptual operationalization: Internationalization of societal failures, Global allocation of } \\
\text { resources, Global stakeholder management, CSR and sustainable development in IB } \\
\text { Non-market strategies to gain legitimacy: Environmental labelling, socially valuable goods } \\
\text { offerings, Subsidiaries and CSR certifications, Overcoming legitimacy through reporting, } \\
\text { Legitimization of new tech through local endorsements } \\
\text { - Other: Standards compliance, Social elites, Shared value creation, Responses to ecological } \\
\text { issues, CSR implementation in subsidiaries, Reducing greenhouse emissions, Non-market } \\
\text { capabilities, Corporate governance and knowledge management }\end{array}$ & $\begin{array}{l}\text { - Critical issues: Marginalized communities, Inequalities created by } \\
\text { internationalization, Globally mobile elite, Pathologies of social collectives, CSR } \\
\text { patronage, Structural violence of globalization, NGO voice } \\
\text { MNE-NGO collaborations: Host-country development, Impact of civil-society } \\
\text { distance, Legitimization of MNE-NGO partnerships, Public-private academic } \\
\text { research } \\
\text { Other: Improvement of CSR language resources, Review of social responsibility } \\
\text { in IB }\end{array}$ \\
\hline
\end{tabular}




\subsection{Biographical note}

Noemi Sinkovics (PhD, Manchester) is Lecturer in International Business and Management at Alliance Manchester Business School, UK and currently Visiting Scholar at Temple University, Fox School of Business, Philadelphia, PA, U.S.A. Her research focuses on international entrepreneurship, supplier capability development and upgrading in emerging markets, and issues related to the business society interface including social value creation, business ethics and responsible innovation. She has published in journals such as

International Business Review, International Marketing Review, Journal of Business Research, Critical Perspectives on International Business, Journal of International Management, and European Journal of International Management. Email: noemi.sinkovics@manchester.ac.uk

Rudolf R. Sinkovics (PhD, WU Vienna) is Professor of International Business at The University of Manchester, UK, Visiting Professor at Lappeenranta University of Technology, Finland, and Visiting Scholar at Fox School of Business, Temple University. He has published on inter-organizational governance, the role of ICT in firm internationalization, and currently works on rising powers and responsible business. His work has been published in Journal of International Business Studies, Management International Review, Journal of World Business, International Business Review, Critical Perspectives on International Business and International Marketing Review, amongst others. Email:

Rudolf.Sinkovics@manchester.ac.uk

Jason Archie-Acheampong is a Postgraduate Research Student at Alliance Manchester Business School, UK. He obtained a master's degree in entrepreneurship and works on issues related to SMEs' responsible behavior. Email: jason.archie-acheampong@manchester.ac.uk 